\title{
Reminiscencje z podróży Polaków po Sudetach na podstawie XIX-wiecznych relacji
}

\author{
Aneta Marek \\ https://orcid.org/0000-0002-4816-1730 \\ Uniwersytet Wrocławski
}

Zarys treści: W artykule zaprezentowano etapy stopniowego poznawania Sudetów poprzez wieki. Głównym celem było przedstawienie opisów i relacji publikowanych przez Polaków w XIX w. Pierwsi wędrowcy zapisywali swoje wrażenia z odwiedzanego regionu w lokalnych dziennikach i kronikach, łącząc ze sobą różnorodne wątki tematyczne: przyrodnicze, historyczne czy społeczno-gospodarcze. Spostrzeżenia te zostały poczynione podczas pobytów Polaków w górach, uzdrowiskach oraz obiektach antropogenicznych.

Słowa kluczowe: Sudety, wędrówki, turystyka, relacje

Sudety są rozległym łańcuchem górskim położonym na terytorium trzech krajów i stanowiącym północno-wschodnie ograniczenie potężnego Masywu Czeskiego. Przyjmuje się, że ich zachodnią granicą jest przełomowa dolina Łaby, wschodnią zaś - Brama Morawska ${ }^{1}$, będąca szerokim obniżeniem pomiędzy Sudetami a Karpatami. Sudety rozciągają się z północnego zachodu na południowy wschód na długości ok. $340 \mathrm{~km}$, przy szerokości dochodzącej do ok. $60 \mathrm{~km}$. Na terenie Polski północną granicę łańcucha wyznacza struktura morfologiczna sudeckiego uskoku brzeżnego przebiegająca na linii: Złotoryja, Dobromierz, Złoty Stok, południowo-zachodnią natomiast - krawędź morfologiczna nasunięcia łużyckiego ${ }^{2}$. Sudety zostały podzielone na kilka mniejszych jednostek, co podyktowały budowa geologiczna oraz procesy geomorfologiczne

\footnotetext{
${ }^{1}$ J. Potocki, Funkcje turystyki w ksztattowaniu transgranicznego regionu górskiego Sudetów, Wrocław 2009.

2 K.R. Mazurski, Geografia turystyczna Sudetów, Wrocław 2003; A. Marek, I.J. Olszak, Położenie Sudetów, jednostki fizyczno-geograficzne, w: Sudety i Przedgórze Sudeckie. Środowisko, ludność, gospodarka, red. A. Marek, I.J. Olszak, Wroctaw 2014, s. 7-30.
}

Abstract: The article presents the stages of gradual exploration of the Sudetes over the centuries. The main objective was to present descriptions and accounts published by Poles in the $19^{\text {th }}$ century. The first wanderers gave their impressions of the visited region in local newspapers and chronicles, combining various thematic threads such as natural, historical, and socio-economic. These observations were taken into account based on the visits of Poles in the mountains, spas and anthropogenic facilities.

Keywords: Sudetes, travelling, tourism, relations

kształtujące rzeźbę terenu przez ostatnie kilkadziesiąt milionów lat. Ze względu na położenie fizycznogeograficzne obszar łańcucha w obrębie Polski podzielony został na: Sudety Zachodnie, Sudety Środkowe i Sudety Wschodnie.

Po raz pierwszy nazwa Sudety została użyta w II w. n.e., gdy grecki uczony Klaudiusz Ptolemeusz umieścił na mapie Germanii Wschodniej i Sarmacji pasmo pod nazwą Sudeti Montes w trudnym do zlokalizowania dziś miejscu³. Jednym z najstarszych dokumentów kartograficznych, w którym pojawia się określenie Sudety, jest odnaleziona w latach trzydziestych XIX w. w benedyktyńskim klasztorze w Ebstorfie średniowieczna mappa mundi, powstała prawdopodobnie ok. 1284 r. $^{4}$ Najstarsze opracowania kartograficzne interesującego nas obszaru obarczone były wieloma błędami w zakresie lokalizacji i nazewnictwa. Pierwszą mapę z poprawnie naniesionym pasmem Sudetów opracował w drugiej

\footnotetext{
M. Staffa, Karkonosze, Wrocław 2001

${ }^{4}$ J. Staszewski, Mappa mundi z Ebstorfu jako źródło wiedzy geograficznej średniowiecza, „Przegląd Geograficzny”, 38 (2), 1966, s. 183-190.
} 
połowie XV w. filozof kard. Mikołaj z Kuzy. Wzniesienia zobrazowane zostały na niej w formie kopczyków, a obok nich znalazły się toponimy: Sudety, Śląk i Odra. Warto podkreślić, że kartografia regionalna zaczęła się rozwijać w XVI w. Przykładowo w 1544 r. jako dodatek do dzieła Kosmografia Sebastiana Münstera ukazała się w Bazylei opracowana przez niego mapa Śląska, a w 1561 r. wydane zostało pierwsze szczegółowe opracowanie kartograficzne tego obszaru autorstwa Marcina Helwiga, na którym zaprezentowano właściwą lokalizację i nazewnictwo niektórych sudeckich obiektów geograficznych. Do XVIII w. mapa Helwiga stanowiła podstawę regionalnych opracowań, dlatego też śląski historyk Christian Runge uznał ją za "matkę wszystkich innych map Śląska" . Kolejne opracowania kartograficzne, zwłaszcza powstające w XVI-XVIII w., odzwierciedlały ówczesny stan wiedzy o Sudetach, przyczyniając się do stopniowego wzrostu zainteresowania tymi górami.

Sudety są regionem stosunkowo bogatym $\mathrm{w}$ walory przyrodnicze $\mathrm{i}$ antropogeniczne. Ich unikatowość wynika ze zróżnicowanej budowy geologicznej, urozmaiconej rzeźby terenu i sieci hydrograficznej, ale również z elementów antropogenicznych, reprezentowanych przez obiekty sakralne, rezydencjonalne, warowne i przemysłowe. Przez stulecia Sudety poddawane były wpływom czeskim, polskim, austriackim oraz niemieckim, dlatego też stanowią dziś interdyscyplinarne pole zainteresowań i badań. Przed 1945 r. uznawane były za najwyższe pasmo górskie Prus i północnych Niemiec ${ }^{6}$. Położenie blisko dużych ośrodków miejskich, jak Wrocław, Berlin czy Drezno, sprzyjało odpowiedniemu zagospodarowywaniu, także w obszarze turystycznym. W XIX w. Sudety stanowiły obiekt zainteresowania

\footnotetext{
${ }^{5}$ A. Osowska, Sudety na dawnych mapach, w: Sudety i Przedgórze Sudeckie, s. 31-51.

${ }^{6}$ J. Potocki, Rozwój zagospodarowania turystycznego Sudetów od połowy XIX wieku do II wojny światowej, Jelenia Góra 2004.
}

zarówno niemieckich, jak i polskich podróżników i kuracjuszy.

\section{Przegląd literatury}

Publikacje związane z odkrywaniem Sudetów można podzielić na dwie grupy. Pierwszą stanowią wszelkie zapiski, wspomnienia, pamiętniki i relacje publikowane przez osoby odwiedzające Sląsk na łamach XIX-wiecznej prasy. Historyk Wacław Odyniec $^{7}$ wyróżnił w swojej publikacji o historii turystyki następujące ich grupy: diariusze regularne, diariusze nieregularne, pamiętniki, pamiętniki-przewodniki turystyczne, relacje epistolograficzne i poematy podróżnicze. Stanowią one cenne źródło informacji naocznych świadków, wędrowców, którzy odnotowywali zarówno podstawowe informacje przydatne dla podróżnych, jak również treści przyrodnicze, krajobrazowe, historyczne, patriotyczne, religijne, społeczno-gospodarcze, podania, legendy, a także wzmianki dotyczące obyczajów panujących w danym regionie czy regulacje obowiązujące w uzdrowiskach. W większości takich opisów autorzy uwzględniali również aspekt duchowy i emocjonalny, podkreślając przeżycia, jakie towarzyszyły im podczas peregrynacji. Treść wielu z takich publikacji pozwala je uznać za pierwsze informatory krajoznawcze i przewodniki turystyczne.

Drugą grupę interesujących nas tekstów stanowią opracowania i monografie dotyczące historii polskiej turystyki. W bardziej ogólny sposób zagadnienie to przedstawili Zbigniew Kulczycki ${ }^{8}$, Małgorzata Lewan", Jerzy Gaj ${ }^{10}$, a następnie Marianna i Roman Łazarkowie $^{11}$. Wątki dotyczące historii sudeckiej turystyki są w tych pracach raczej

\footnotetext{
${ }^{7}$ W. Odyniec, Z dziejów polskiej turystyki od XVI wieku do roku 1939, Gdańsk 1993

${ }^{8}$ Z. Kulczycki, Zarys historii turystyki w Polsce, Warszawa 1977.

${ }^{9}$ M. Lewan, Zarys dziejów turystyki w Polsce, Kraków 2004.

${ }^{10} \mathrm{~J}$. Gaj, Zarys historii turystyki w Polsce w XIX i XX wieku, Poznań 2001; tenże, Zarys historii turystyki w Polsce, Warszawa 2003; tenże, Dzieje turystyki w Polsce, Warszawa 2008.

${ }^{11}$ M. Łazarek, R. Łazarek, Śladami historii turystyki. Od starożytności do wspótczesności, Lublin 2005.
} 
poboczne, jednakże kwestie kształtowania się ruchu turystycznego w Polsce zostały omówione kompleksowo. Ważne miejsce zajmuje publikacja Władysława Krygowskiego pt. Zarys dziejów polskiej turystyki górskiej $^{12}$, ukazująca tło rozwoju turystyki (głównie tatrzańskiej, ale także sudeckiej), omawiająca działalność podróżników i prezentująca różne organizacje turystyczne i krajoznawcze. Jedną z ważniejszych publikacji, które ukazały się w ostatnich latach, jest Historia turystyki sudeckiej Krzysztofa Radosława Mazurskiego ${ }^{13}$. Autor pokazuje w niej stopniowe poznawanie Sudetów od czasów najdawniejszych po współczesność, zarówno po polskiej, jak i czeskiej stronie gór. Na szczególną uwagę zasługują również książki Tomasza Przerwy - Wędrówka po Sudetach i Odkryli dla nas piękno gór a także przygotowana pod jego redakcją monografia W cieniu Wielkiej Sowy, choć dwie ostatnie dotyczą głównie Sudetów Środkowych ${ }^{14}$. Niezwykle wartościowe są informacje podkreślające działalność niemieckich towarzystw górskich, które przyczyniły się do zagospodarowania terenu i tym samym rozwoju turystyki. Pisali o tym m.in. Marcin Dziedzic i Tomasz Przerwa $^{15}$. Aspekty dotyczące poznawania Sudetów w ujęciu chronologicznym prezentują natomiast m.in. publikacje Tadeusza Stecia i Wojciecha Walczaka ${ }^{16}$, Marka Staffy ${ }^{17}$ oraz Zbigniewa Kulika ${ }^{18}$.

Bezcennym źródłem wiedzy o rozwoju polskiej turystyki są opracowania Ryszarda Kincla, który dość skrupulatnie opisał

\footnotetext{
12 W. Krygowski, Zarys dziejów polskiej turystyki górskiej, Warszawa 1973.

${ }^{13}$ K. R. Mazurski, Historia turystyki sudeckiej, Kraków 2012.

14 T. Przerwa, Wędrówka po Sudetach. Szkice z historii turystyki śląskiej przed 1945 r., Wrocław 2005; tenże, Odkryli dla nas piękno gór, Toruń 2003; W cieniu Wielkiej Sowy. Monografia Gór Sowich, red. T. Przerwa, Dzierżoniów 2006

${ }^{5}$ M. Dziedzic, Kłodzkie Towarzystwo Górskie 1881-1945, Wrocław 2013; T. Przerwa, Organizacje turystyczne na Ziemi Kłodzkiej do 1945 r. Zarys problematyki badawczej, „Kládský sborník”, 5, 2003, s. 143-151.

${ }^{16}$ T. Steć, W. Walczak, Karkonosze. Monografia krajoznawcza, Warszawa 1962.

${ }^{17}$ M. Staffa, Karkonosze; tenże, Historia poznania Karkonoszy oraz rozwój osadnictwa, w: Karkonosze. Przyroda nieożywiona i człowiek, red. M.P. Mierzejewski, Wrocław 2005.

${ }_{18}$ Z. Kulik, Historia poznania gór, w: Karkonosze polskie, red. A. Jahn, Wrocław i in. 1985, s. 427-439.
}

kształtowanie się w Sudetach przewodnictwa turystycznego. Niezwykle przydatne były wśród nich Początki przewodnictwa turystycznego w Karkonoszach, Poczatki turystyki i przewodnictwa na Ziemi Ktodzkiej, a także Sarmaci na Śnieżce oraz U szlaskich $w^{\prime} d^{19}$. Ciekawe wydają się też publikacje Jacka Kolbuszewskiego $-Z$ dziejów Snieżki w Karkonoszach oraz Krajobraz $i$ kultura ${ }^{20}$ - a także $Z$ kuferkiem i chlebakiem Juliana Janczaka ${ }^{21}$. Treść historyczna często uzupełniana jest $\mathrm{w}$ nich zapiskami romantycznych wędrowców, podkreślającymi ich wrażenia, emocje i wyobrażenia o krajobrazie ówczesnego Śląska. Podobny charakter mają dwa opracowania Andrzeja Zielińskiego - Polskie podróże po Ślasku w XVIII i XIX wieku oraz Listy ze ślaskich wód-zawierające wybrane rozważania podróżników i kuracjuszy z XIX-wiecznych pamiętników i czasopism ${ }^{22}$.

Dzieje turystyki sudeckiej były również przedmiotem opracowań wielu naukowców i znawców tematyki regionalnej, które ukazywały się jako rozdziały monograficzne lub artykuły w czasopismach naukowych i popularnonaukowych. Problematyka ruchu turystycznego prezentowana była m.in. przez Jana Reychmana ${ }^{23}$, Krzysztofa Jaworskiego ${ }^{24}$, Zbigniewa Kulika ${ }^{25}$, Tadeusza Stecia ${ }^{26}$, Juliana Janczaka ${ }^{27}$, Zbisława

\footnotetext{
${ }_{19}$ R. Kincel, Początki przewodnictwa turystycznego w Karkonoszach, Jelenia Góra 1972; tenże, Początki turystyki i przewodnictwa na Ziemi Kłodzkiej, w: V Forum Krajoznawstwa Dolnośląskiego, Polanica-Zdrój 1976, s. 9-35; tenże, Sarmaci na Śnieżce, Wrocław 1973; tenże, U szląskich wód, Racibórz 1994

20 J. Kolbuszewski, Z dziejów Śnieżki w Karkonoszach, Warszawa-Kraków 1990; tenże, Krajobraz i kultura, Katowice 1985.

${ }^{21}$ J. Janczak, Z kuferkiem i chlebakiem, Warszawa-Kraków 1988.

${ }_{22}$ A. Zieliński, Polskie podróże po Śląsku w XVIII i XIX wieku, Wrocław i in 1974; tenże, Listy ze śląskich wód, Wroctaw i in. 1983

${ }^{23}$ J. Reychman, Turystyka polska w Sudetach przed 1945 r., ,Wierchy”, 40, 1971, s. 20-38.

${ }^{24}$ K. Jaworski, Turystyka polska w czeskich Sudetach w XVIII i XIX wieku, „Acta Universitatis Wratislaviensis”, 2055 (3), 1998, s. 9-19.

${ }^{25}$ Z. Kulik, Wędrówki na Śnieżkę w I połowie XVIII wieku, „Rocznik Jeleniogórski", 16, 1978, s. 78-92

${ }^{26}$ T. Steć, Przyczynki do dziejów turystyki w Karkonoszach, „Wierchy”, 24 1955, s. 116-122

${ }^{27}$ J. Janczak, Z dziejów turystyki śląskiej w XIX i pierwszej połowie XX stulecia, w: I Śląskie Sympozjum Krajoznawców, red. T.J. Rogoża, Opole 1977, s. 5-12.
} 
Michniewicza $^{28}$, Jacka Kolbuszewskiego ${ }^{29}$ i Jacka Potockiego ${ }^{30}$. Na wyróżnienie zasługują również opracowania, w których dokonano analizy pierwszego polskojęzycznego przewodnika o Karkonoszach, napisanego przez warszawiankę Rozalię Saulsonowa. Był on obiektem zainteresowania m.in. Jacka Kolbuszewskiego ${ }^{31}$ oraz Ivona Łaborewicza ${ }^{32}$. Tematyką zagospodarowania turystycznego Sudetów zajmowali się natomiast m.in. Jacek Potocki, Tomasz Dudziak, Wojciech Ciężkowski, Jan Szwarc, Wojciech Kosiński, Barbara Setkowicz i Janusz Trojanowski ${ }^{33}$.

\section{Pionierskie penetracje Sudetów}

Pasma górskie przyciągały uwagę człowieka od zamierzchłych czasów. Pogański kult religijny zaczął obejmować różne obiekty przyrodnicze: ludzie obdarzali czcią słońce, księżyc, ogień czy źródła rzek. $\mathrm{Z}$ wieloma takimi miejscami wiązały się tajemnice, przesądy i legendy. Za przykład mogą tu służyć postać wędrującego po Karkonoszach Ducha Gór, znanego jako Liczyrzepa, Karkonosz, Rzepiór, Rzepolicz (niem. Rübezahl, czes. Krkonoš) czy Flinsa, zwanego też Lwińcem, którego kult rozwijał się na Łużycach i w Górach Izerskich $^{34}$. Najbardziej znanym szczytem

${ }^{28}$ Z. Michniewicz, Szkic dziejów turystyki śląskiej w Karkonoszach, „Rocznik Wrocławski", 3-4, 1959-1960, s. 372-392; tenże, Z dziejów turystyki polskiej w Karkonoszach (na początku XIX wieku), ,Wierchy”, 25, 1956, s. 42-56.

${ }^{29}$ J. Kolbuszewski, Kilka uwag o dawnych wycieczkach na Śnieżkę w Karkonoszach, „Góry, Literatura, Kultura”, 11, 2018, s. 15-41.

${ }^{30}$ J. Potocki, Śnieżka jako cel wędrówek imiejsce kultu religijnego, w: Kultura i turystyka. Sacrum i profanum, red. J. Mokras-Grabowska, J. Latosińska, Łódź 2016, s. 101-115.

${ }^{31}$ J. Kolbuszewski, Najdawniejszy polski przewodnik po Karkonoszach, „Wierchy”, 48, 1979, s. 257-261; tenże, Rozalii rady i wskazówki (0 najdawniejszym polskim przewodniku górskim), ,Rocznik Jeleniogórski”, 18, 1980, s. 177-190.

${ }^{32}$ I. Łaborewicz, Co nowego wiemy o Rozalii Saulson ijej pobycie w Cieplicach Śląskich-Zdroju?, ,Wierchy”, 65, 1999, s. 178-182.

33 J. Potocki, Rozwój; tenże, Funkcje; J. Potocki, T. Dudziak, Zarys dziejów znakowania szlaków turystycznych w Sudetach, w: Szlaki turystyczne a przestrzeń turystyczna, red. P. Kuleczka, Warszawa 2007, s. 201-214; W. Ciężkowski, J. Szwarc, Śnieżnik. Dzieje zagospodarowania szczytu, „Pielgrzymy”, 1986, s. 19-29; W. Kosiński, B. Setkowicz, J. Trojanowski, Zagospodarowanie Śnieżnika, „Wierchy”, 49, 1980, s. 5-27.

${ }^{34}$ K.R. Mazurski, Lwiniec i Świeradów Zdrój, „Informator Krajoznawczy”, 3-4, 1984, s. 23-26. górskim noszącym ślady kultu religijnego jest położona na Przedgórzu Sudeckim Ślęża. Zachowane tam tajemnicze znaki solarne, kręgi kultowe, rzeźby oraz święte gaje mogły wskazywać, że było to miejsce obrzędów pogańskich. Ważnym punktem rytualnym były również źródła Łaby: „Pierwsze wyprawy w Karkonosze nie były podejmowane ani z ciekawości, ani dla jakiś korzyści, lecz wypływały z głębokiej czci, jaką Słowianie czescy żywili dla sił przyrody objawiających się w odwiecznym rodzeniu się rzeki: początek dał im kult źródeł Łaby" ${ }^{35}$. Jak pisał jeden z czołowych polskich taterników i historyków literatury Mieczysław Świerz, „obserwacya rzeczywistości nie kłóciła się zatem $\mathrm{z}$ wiarą w duchy i czary, a prawdziwa nauka godziła się z zabobonami i przeświadczeniem o istnieniu cudów”"36. Steć zauważał z kolei: „Jest rzeczą osobliwą, że [...] ludzie udają się do źródeł Łaby w Karkonoszach i tam zgodnie ze starym zwyczajem wypuszczają czarne koguty. [...] jest rzeczą oczywistą, że przesąd ten sięga jeszcze czasów słowiańskiego pogaństwa" ${ }^{37}$.

Do innych sudeckich obiektów stanowiących domniemane miejsca kultu można zaliczyć Ostrzycę na Pogórzu Kaczawskim czy Dobre Źródło ulokowane na stoku Grabowca na Pogórzu Karkonoskim. Czcią darzono także Wolframowe Źródło w Górach Izerskich (nazywane również źródłem św. Wolfganga). W wielu przekazach to ostatnie łączone było z kultem wspomnianego już łużyckiego bożka Flinsa. Prześladowani Łużyczanie pozostawili jego figurkę na stoku jednej z gór, nazywając ją górą Białego Flinsa ${ }^{38}$. Wzmianka o słowiańskim bożku pojawiła się również w opisie Stanisława Staszica, który charakteryzował odwiedzane przez siebie regiony pod kątem geologicznym.

\footnotetext{
${ }^{35}$ Z. Kulik, Historia, s. 427-439.

${ }_{36}$ M. Świerz, Zarys dziejów taternictwa polskiego, „Pamiętnik Towarzystwa Tatrzańskiego", 34, 1913, s. 49-69.

${ }^{37}$ T. Steć, W. Walczak, Karkonosze.

${ }^{38}$ K.R. Mazurski, Lwiniec, s. 23-26.
} 
Nazwa góry Flins nawiązuje jego zdaniem do nazwiska „bożka śmierci u Serbow i Wendenczykow, który tu z dawnych podań miał mieć kościól” ${ }^{39}$. O przejawach kultu Flinsa zaznajamiał też czytelników w poemacie Szlask podróżnik i krajoznawca Bogusz Stęczyński: „Jest to Flins = kamień szary, ogromnéj wielkości, / Na niem rozpłomieniano w dnie uroczystości / Święte ognie Bogowi temu poświęcone" 40 .

Do rozpowszechniania wyobrażeń na temat gór oraz wiedzy o ewentualnych zagrożeniach dochodziło w wyniku przemieszczania się ludności w celach handlowych. Przez Sudety prowadziły liczne trakty, spośród których najważniejszą rolę odgrywał szlak bursztynowy. Według Stecia i Walczaka w okresie średniowiecza na terenie Karkonoszy istniały jeszcze co najmniej dwa trakty handlowe: Śląska Droga oraz Czeska Ścieżka ${ }^{41}$.

Przez średniowiecznych historyków i kronikarzy góry postrzegane były jako miejsca trudno dostępne i często niebezpieczne. W ich relacjach nie brakowało istotnych wiadomości o trudach, jakie muszą przezwyciężyć przemierzający je podróżni i żołnierze. Przykładem jest opis zawarty w Kronice Marcina Galla: „[...] od strony Polski Morawy tak dalece są najeżone gór spadzistością i gęstwą lasów, iż nie dla konnych już hufów, lecz dla zaprawnych nawet do różnych niebezpieczeństw pieszych wędrowców są niedostępnemi”². Innym razem kronikarz podkreślał trudności, z jakimi w 1138 r. przyszło się zmagać podczas przeprawy przez Karkonosze królowi Bolesławowi III Krzywoustemu: „[...] może być porównany z Hannibalem i jego nadzwyczajnym czynem. Albowiem tak jak on, idąc na zdobycie Rzymu,

\footnotetext{
${ }^{39}$ S. Staszic, 0 ziemiorództwie Karpatów i innych gór i równin Polski, Warszawa 1815.

40 Szląsk. Podróż malownicza, w 25-ciu pieśniach wyśpiewał Bogusz Zygmunt Stęczyński, Wrocław 1851, rkps, Zakład Narodowy im. Ossolińskich, sygn. 3424/, s. 154

${ }^{41}$ T. Steć, W. Walczak, Karkonosze.

${ }^{42}$ Z. Komarnicki, Kronika Marcina Galla przełożona na język polski i objaśniona, Warszawa 1873.
}

pierwszy dokonał przejścia przez górę Jowisza, tak Bolesław, chcąc najechać Czechy, zapuścił się w miejsca grozę budzące, gdzie przedtem nie stanęła ludzka stopa" ${ }^{\prime 3}$.

Kolejny etap penetracji gór wiązał się z poszukiwaniem i pozyskiwaniem najróżniejszych bogactw do celów gospodarczych. Człowiek zaczął się zapuszczać w coraz wyższe partie gór, pchany nadzieją pozyskania kruszców, drogocennych kamieni i minerałów. Specjalizowali się w tym Walonowie, zwani również Walończykami. Pierwsza ich fala przybyła w Karkonosze w XII i XIII w. z pogranicza Francji i Belgii. Zanim pojawili się w Sudetach, penetrowali góry Harcu i Rudawy ${ }^{44}$. Celem ich działalności było przede wszystkim pozyskiwanie złota, ale również kamieni szlachetnych i półszlachetnych. XV i XVI w. to początek drugiego okresu migracji poszukiwaczy w Karkonosze i Góry Izerskie, tym razem głównie $\mathrm{z}$ Włoch (Wenecji i Florencji) oraz Niemiec. Bez względu na pochodzenie nazywano ich jednak wówczas wszystkich Walonami. Jeden z poszukiwaczy, Jeremiasz Vincentius, podkreślał bogactwo Karkonoszy, które przyniosło mu fortunę, zamieszczając na frontonie swojej weneckiej rezydencji napis: „Góry Karkonosze uczyniły nas panami” ${ }^{45}$. Kamienie szlachetne stały się wysoce pożądanym materiałem zdobniczym dla siedzib królewskich. W czeskiej kronice Hajka z Libočan zanotowano, że „król czeski Karol IV rozkazał poszukiwać barwnych kamieni w celu wystrojenia kaplicy św. Wacława. I znaleziono pod Górami Karkonoskimi wiele dużych, twardych i barwnych kamieni. I kazał je polerować i wyłożyć nimi ściany kaplicy” ${ }^{46}$.

\footnotetext{
${ }^{43}$ T. Pełech, Hannibal ante portas. Interpretacja fabuty z 21 rozdziału III księgi Kroniki polskiej Anonima tzw. Galla, „Meluzyna. Dawna Literatura i Kultura”, 1 (4), 2016, s. 5-13.

${ }^{44}$ W Polsce określane jako Rudawy, w Czechach znane są one pod nazwa Krušne hory. Zob. T. Steć, W. Walczak, Karkonosze; Z. Kulik, Historia, s. 427-439.

45 A. Andrejew, Trasy wędrówek krajoznawczo-naukowych Kaspra Schwenckfeldta po Sudetach Zachodnich, „Wierchy”, 61, 1995, s. 115-124.

${ }^{46}$ V. Hájek z Libočan, Kronika česká, [t.] 4: Čechy královské. R. 1254 1347, Praha 1933
} 
Na przełomie XIV i XV w. prace poszukiwawcze na dużą skalę zaczęto prowadzić w wielu innych rejonach górskich Sudetów: w Masywie Śnieżnika, Górach Złotych czy Górach Sowich, a obok górnictwa zaczęły się rozwijać hutnictwo i szklarstwo. Funkcjonowanie tych trzech pierwotnych gałęzi przemysłu wymagało wycinania znacznych połaci drzewostanu. Drwale transportowali drewno $\mathrm{z}$ trudno dostępnych partii gór specjalnymi ryzami i spławiali je rzeką. $\mathrm{Na}$ potrzeby hutnictwa i szklarstwa wyrabiany był węgiel drzewny, a zajmowali się tym węglarze, zwani także kurzakami.

Dużą rolę w poznawaniu gór odgrywali również zielarze, a leczenie preparatami roślinnymi spotykane było $\mathrm{w}$ osiedlach górskich całego świata. Jednym z pierwszych botaników, który odwiedził Karkonosze, był Włoch Petrus Andreas Matthioli. Dokonane przez niego opisy stały się następnie podstawą działalności Kaspara Schwenckfeldta ${ }^{47}$, koncentrującego swoje zainteresowania wokół sudeckiej flory, ale również kruszców (tego ostatniego niewątpliwie można uznać za odkrywcę Karkonoszy i pioniera sudeckich wędrówek). Po 1700 r. w Karpaczu powstał cech zbieraczy ziół, zwanych laborantami. Preparowali oni $\mathrm{z}$ roślin - w szczególności górskich - rozmaite mikstury, proszki i maści. O wysokich kwalifikacjach i rozwoju tej grupy świadczy fakt, że medykamenty wysyłane były do różnych miast, m.in. Wrocławia i Lipska ${ }^{48}$. Cech laborantów zakończył swoją działalność w XIX w. Zdaniem Wilhelma Winklera - nauczyciela ze Szklarskiej Poręby i autora podręcznika o florze sudeckiej z 1900 r. - proceder pozyskiwania roślin przyczynił się do ich znacznej dewastacji: „Od lat na tutejszych grzbietach górskich różne rośliny, a zwłaszcza Primula minima, są zbierane przez osoby zarobkujące $\mathrm{z}$ ich sprzedaży.

\footnotetext{
${ }^{47}$ A. Andrejew, Trasy, s. 115-124; tenże, Kaspar Schwenckfeldt - renesansowy badacz przyrody karkonoskiej, „Rocznik Jeleniogórski”, 19, 1981, s. 63-76.

48 Z. Domosławski, Medycyna górska, w: Karkonosze polskie, s. 441-442.
}

Całe bele tych jedynych w swoim rodzaju kwiatów są pakowane i wysyłane i w ten sposób nasze wysokie góry są plądrowane bez żadnych skrupułów" ${ }^{49}$.

$\mathrm{Z}$ pozoru niedostępne góry pozwalały ukrywać się rozbójnikom i ludziom wyjętym spod prawa, ale stanowily też miejsce schronienia ludności (głównie protestanckiej) podczas prześladowań religijnych. Przykładem są Góry Stołowe, na terenie których dyskryminowani mieszkańcy znajdywali schronienie w skalnych labiryntach $^{50}$. Warto wspomnieć, że miejscem potajemnych spotkań braci czeskich były niedostępne skały Ostaša ${ }^{51}$. Na jednej z jego ścian wykuto cyfry oznaczające rok 1627 oraz kielich - symbol tego ruchu (ryc. 1).

\section{Turystyka w Sudetach}

Mimo że jeszcze w XVII w. europejskie góry powszechnie budziły przerażenie wśród wędrowców, to Karkonosze stawały się już w tym okresie coraz bardziej popularne. Jednym z pierwszych potwierdzonych wyjść w Góry Olbrzymie, jak nazywano wówczas Karkonosze, była dydaktyczna wycieczka szkolna przygotowana w $1564 \mathrm{r}$. przez rektora jeleniogórskiego gimnazjum Krzysztofa Schillinga. Przez dwa lata organizował i prowadził uczniów, osiągając z nimi Śnieżkę czy docierając do źródeł Łaby $^{52}$. Warto zaznaczyć, że zainteresowanie budziła również południowa część Karkonoszy. W latach 1576-1585 kilka wypraw w te góry odbył Simon Hüttel z Trutnova, co zaowocowało stworzeniem mapy najwyższego sudeckiego pasma, na której zaznaczone zostało czterysta trzydzieści nazw obiektów geograficznych ${ }^{53}$.

\footnotetext{
${ }^{49}$ K. Hempel, Z dziejów zielarstwa w Sudetach, „Wierchy”, 27, 1958, s. $188-189$.

${ }^{50}$ J. Szczepankiewicz-Battek, Zbór Braci Czeskich w Górach Stołowych, „Pielgrzymy”, 1997 s. 87-93.

51 J. Rủžička, J. Jordáková, Z. Pozlovská, Skalní města do kapsy, Praha 2006, s. 444

${ }^{52}$ K.R. Mazurski, Historia.

${ }^{53}$ M. Bartoš, P. Klimeš, J. Louda, Nejstarší obrazová mapa Krkonoš, Vrchlabí 2012, s. 60; R. Rzepczyński, Historia podboju królestwa Ducha Gór, czyli szkic z dziejów turystyki u stóp Śnieżki (cz. 1), „Rocznik Jeleniogórski”, 29, 1997, s. 74-86.
} 


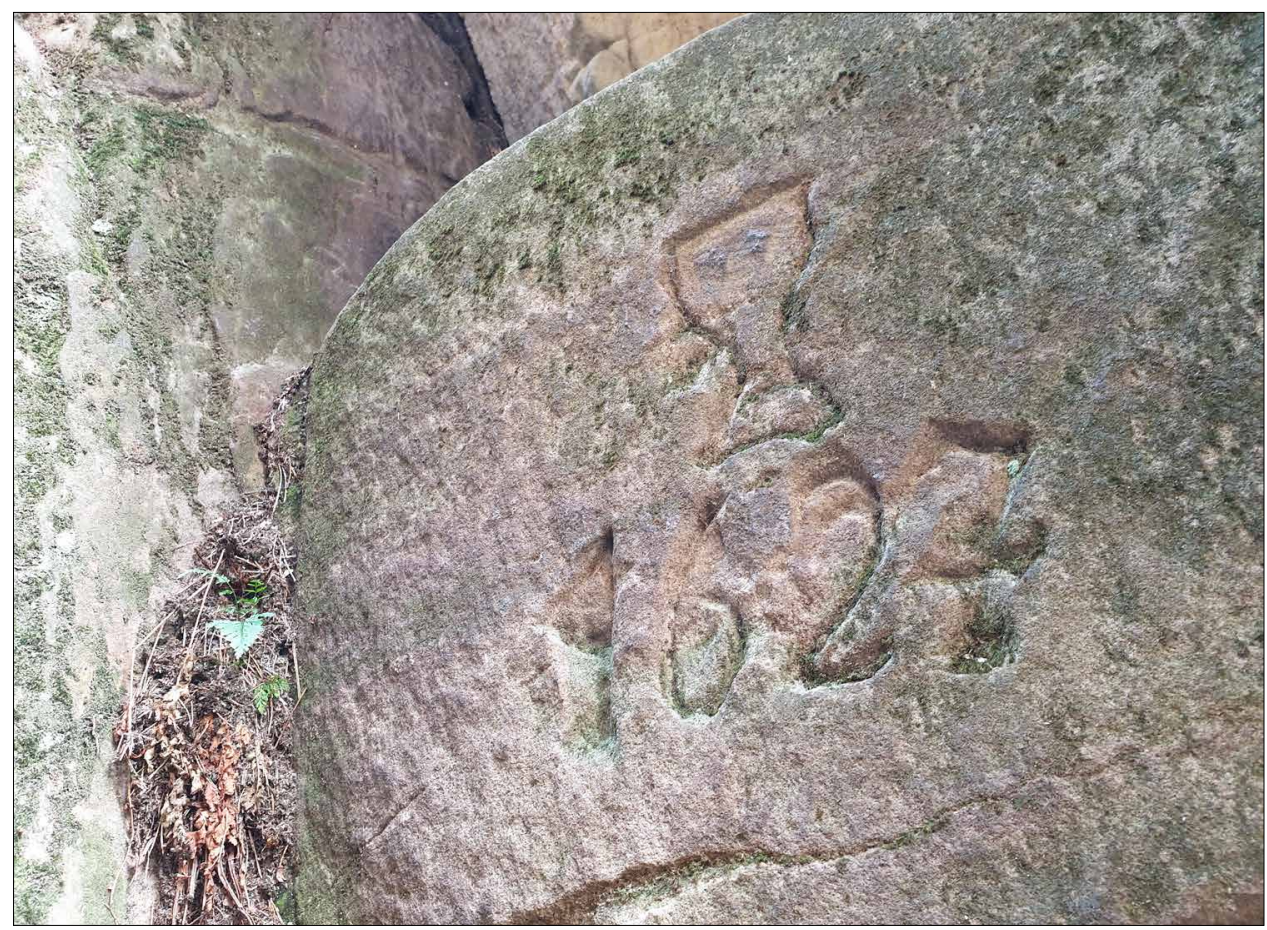

Ryc. 1. Data i kielich wykute na jednej ze ścian skalnego labiryntu Ostaša (fot. A. Marek)

W ten sposób Góry Olbrzymie przestały być terra incognita. Jak już wspomniano na wstępie, w XVI i XVII w. kartografia regionalna nabierała coraz większego znaczenia. Mapy stworzone przez Münstera, Helwiga i wielu innych śląskich kartografów poddawane były różnym modyfikacjom, uzupełnieniom, a niekiedy generalizacji, co zrobił np. Abraham Ortelius. Stosując metodę kopczyków, dokonał ujednolicenia ich wysokości i wielkości $\mathrm{w}$ porównaniu $\mathrm{z}$ mapą Helwiga (ryc. 2, 3). Sprawiło to, że Śnieżka przestała się wyróżniać na tle innych, niższych wzniesień.

W XVII w. pojawiły się pierwsze polskojęzyczne relacje z peregrynacji na obszarze Sudetów. Warto przytoczyć tu postać stolnika żmudzkiego Teodora Billewicza i jego opis podróży, w którą wybrał się w 1677 r. z podkanclerzym litewskim Michałem Kazimierzem Radziwiłłem ${ }^{54}$.

\footnotetext{
${ }^{54}$ E. Szczepański, Z dziejów karkonoskich schronisk (Samotnia), „Rocznik Jeleniogórski", 16, 1978, s. 45-64.
}

Inną interesującą publikacją jest Diariusz Peregrinatiej Niemieckiej Czeskiej $i$ Wtoskiej ziemi, który przynosi pierwszy opis Śnieżki ${ }^{55}$.

Wzrost zainteresowania Karkonoszami nastapił po wybudowaniu w latach 1665-1681 z inicjatywy rodu Schaffgotschów kaplicy na Snieżce. 10 sierpnia 1681 r. odbyło się uroczyste poświęcenie tego obiektu, a trzy lata później, 19 października 1684 r. - poświęcenie źródeł Łaby ${ }^{56}$. Początek turystyce górskiej w Karkonoszach dały zatem pielgrzymki do kaplicy św. Wawrzyńca.

Rosnący ruch turystyczny w Karkonoszach przyczyniał się do stopniowego zagospodarowywania tych ziem. Od XVII w. lokalne chaty pasterskie lub obserwacyjne przekształcane były na skromne obiekty noclegowe zwane budami. Jedną

\footnotetext{
${ }^{55}$ W. Konopczyński, Opis Wroctawia i Cieplic z XVII wieku, „Sobótka”, 3 , 1948, s. 449-452.

${ }^{56}$ J. Kolbuszewski, Z dziejów, s. 14.
} 


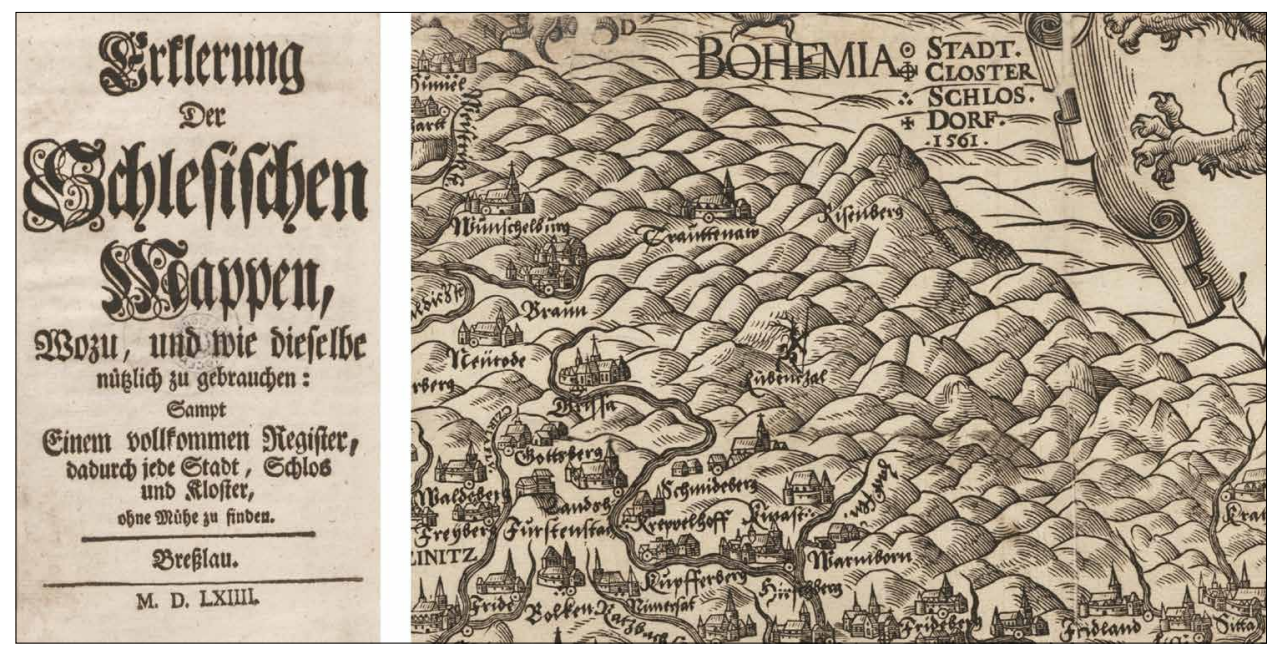

Ryc. 2. Śnieżka na mapie Śląska Marcina Helwiga.

Źródto: zbiory Biblioteki Uniwersyteckiej we Wrocławiu

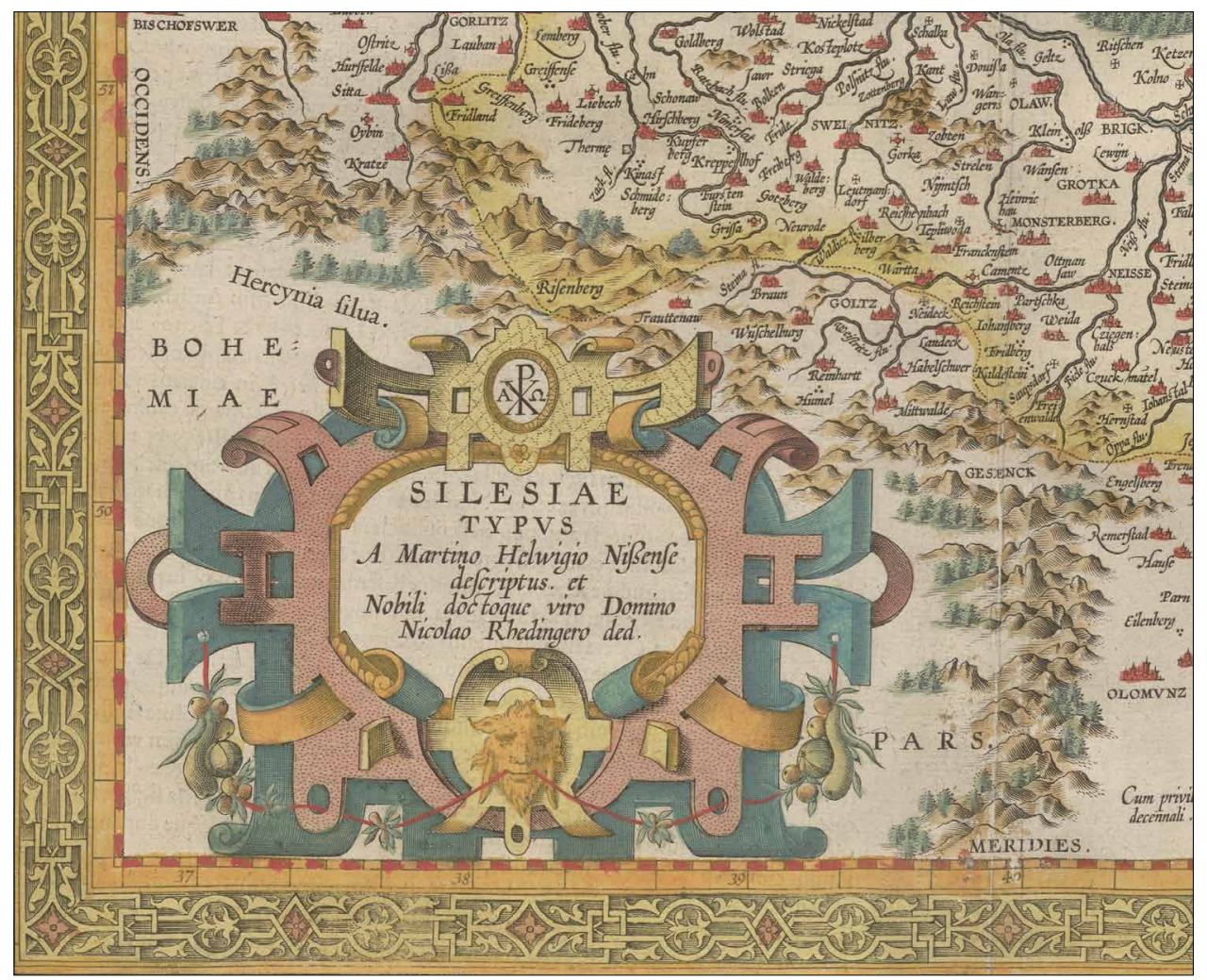

Ryc. 3. Sudety na mapie „Silesia typus” z atlasu Abrahama Orteliusa.

Źródto: zbiory Biblioteki Uniwersyteckiej we Wrocławiu 
z pierwszych była buda na stoku Złotówki nazywana Hampelbaude ${ }^{57}$. Zasadniczo było to po prostu gospodarstwo, ale właściciel udostępniał też miejsca noclegowe podróżnym. Spośród innych XVII-wiecznych obiektów warto przypomnieć domek nad Małym Stawem należący do strażnika pilnującego ryb oraz obiekt pod Łabskim Szczytem, który pierwotnie pełnił funkcję strażnicy na Czeskiej Ścieżce. W niektórych schroniskach wykładano księgi pamiątkowe, stopniowo wprowadzane do bud i gospód od XVII w. Najstarsze zachowane obiekty tego rodzaju pochodzą z bud na Złotówce i Chojniku ${ }^{58}$. Stanowiły one cenny materiał do badań ruchu turystycznego w Karkonoszach.

Pozostałe pasma sudeckie zaczęły zyskiwać na popularności nieco później. Poza Karkonoszami turystyka dość wcześnie zaistniała w Górach Stołowych, zwłaszcza w rejonie Szczelińca Wielkiego. Uważa się, że jednym z pierwszych zdobywców tego szczytu był jezuita, na co wskazuje monogram IHS wykuty w skale zwanej Fotelem Pradziada razem z cyframi oznaczającymi rok $1576^{59}$. Zdaniem Tomasza Przerwy skrót ten należy rozwijać: In hoc signo vinces, czyli 'W tym znaku zwyciężysz'60. Intensywny rozwój turystyki w Górach Stołowych rozpoczął się dopiero w XIX w., po zagospodarowaniu najwyższego szczytu przez Franza Pabla. W 1813 r. otrzymał on od króla pruskiego Fryderyka Wilhelma III pierwszą w Europie urzędową nominację na przewodnika górskiego oraz stanowisko „Mianowany królewski przewodnik i kasjer Szczelińca Wielkiego"61. Pabel był także autorem kroniki Szczelińca, którą wydał drukiem pod nazwą Krótka historia uprzystępniania Szczelinca ${ }^{62}$.

\footnotetext{
${ }^{57}$ T. Przerwa, Wędrówka.

${ }^{58}$ M. Staffa, Karkonosze.

${ }^{59}$ Góry Stołowe. Stownikgeografii turystycznej Sudetów, t. 13, red. M. Staffa, Warszawa-Kraków 1992, s. 232.

${ }^{60}$ T. Przerwa, Wędrówka.

${ }^{61}$ R. Kincel, Początki turystyki, s. 9-35.

62 F. Pabel, Krótka historia uprzystępnienia Szczelińca, ttum. Z. Gdowski, oprac. T. Dudziak, „Pielgrzymy”, 1988, s. 90-124.
}

Dynamiczny ruch turystyczny, zwłaszcza w Karkonoszach, wymagał utworzenia organizacji o charakterze przewodnickim. W 1817 r. królewski starosta w powiecie jeleniogórskim powołał związek pod nazwą Korpus Przewodników i Tragarzy Lektyk i Bagażu ${ }^{63}$. Całkowite uregulowanie spraw przewodnickich i tragarzy lektyk nastąpiło jednak dopiero w 1824 r. $^{64}$

Warto również wspomnieć, że rozwój sudeckiej turystyki przyspieszyły towarzystwa górskie. Pierwszą organizacją tego typu było Towarzystwo Karkonoskie (Riesengebirgsverein - RGV), założone 1 sierpnia 1880 r. w Jeleniej Górze $\mathrm{z}$ inicjatywy Theodora Donata. W marcu 1881 r. powstała druga - Kłodzkie Towarzystwo Górskie (Glatzer Gebirgsverein - GGV) z Robertem Grütznerem na czele jako pierwszym prezesem. W pozostałych pasmach Sudetów działały m.in.: Morawsko-Śląskie Sudeckie Towarzystwo Górskie (Mährisch-Schlesischer Sudetengebirgsverein - MSSGV), Towarzystwo Sowiogórskie (Eulengebirgsverein - EGV), Towarzystwo Górskie z Głuszycy ( $G V$ Wüstegiersdorf), Świdnickie Towarzystwo Górskie (Schweidnitzer Gebirgsverein SGV) i Towarzystwo Ząbkowickie ( $G V$ Frankenstein). Głównymi celami ich działalności były: rozwój zagospodarowania turystycznego, budowa szlaków, schronisk, wież i platform widokowych, ochrona przyrody itp. ${ }^{65}$

\section{Uzdrowiska jako przestrzeń emocji i wrażeń}

Góry dość szybko stały się obiektem zainteresowania kuracjuszy za sprawą rosnącej mody na wyjazdy w celach leczniczych. Funkcje uzdrowiskowe przyjęło wiele górskich i podgórskich miejscowości znanych $\mathrm{z}$ występowania wód, np. Bad Landeck (Lądek-Zdrój), Bad Warmbrunn (Cieplice Śląskie-Zdrój), Bad

\footnotetext{
63 J. Janczak, Z kuferkiem.

64 T. Tyblewski, Rola przewodników turystycznych w wychowaniu, Warszawa 1979.

${ }^{65}$ A. Marek, Historia turystyki, w: Sudety i Przedgórze Sudeckie, s. 383-405
} 
Reinerz (Duszniki-Zdrój), Bad Salzbrunn (Szczawno-Zdrój), Bad Kudowa (Kudowa- Zdrój).

O powstaniu uzdrowiska w Lądku-Zdroju wzmiankuje duchowny Karol Antoniewicz: „Kroniki z 1242 roku wspominają już o kąpielach Landeckich, w którymto roku przez Tatarów zburzone, w roku 1428 podczas wojen Husitów powtórnie ogniem spłonęły!" 66 . Podobne informacje historyczne przytaczał miejscowy lekarz Aleksander Ostrowicz - autor pierwszego polskojęzycznego przewodnika po Lądku-Zdroju i okolicach ${ }^{67}$.

Nieco później, bo w 1281 r., pojawiła się wzmianka o Cieplicach: książę Bernard Lwówecki darował wówczas joannitom ze Strzegomia miejscowość Calidusfons, tzn. 'ciepłe źródła'68. Pisarz i podróżnik Stanisław Bełza wspominał, że w 1687 r. do uzdrowiska Warmbrunn przybyła „z bogatym dworem Marya Kazimiera i przez jakiś czas używała kąpieli”, co przyniosło jej znaczną ulgę w dolegliwościach. Wody Warmbrunnu zostały rozsławione na cały region, a do uzdrowiska przybywali kuracjusze z bliższej i dalszej okolicy ${ }^{69}$. Głównie w XIX w. wyjazdy do wód stały się już swego rodzaju modą i sposobem na podkreślenie swojej pozycji i prestiżu. Za trendem wyznaczanym przez przedstawicieli rodów królewskich i arystokratycznych oraz bogatą szlachtę podążali mieszczanie.

Uzdrowisko w Cieplicach odwiedzili m.in. Hugo Kołłątaj (1792, 1808), Wojciech Bogusławski (1801), Józef Wybicki (1802), Izabela Czartoryska (1816) i Wincenty Pol (1847). Na kuracji w Szczawnie-Zdroju bywali: brat Marii Walewskiej Józef Łączyński (1820), Zygmunt Krasiński (1838), Bogusz Maciej Stęczyński

\footnotetext{
${ }^{66}$ K. Antoniewicz, Wspomnienia z wędrówki przez Góry Olbrzymie (Riesengebirge) w roku 1837, „Rozmaitości” [pismo dodatkowe do "Gazety Lwowskiej"], 7, 1838, s. 54-55.

${ }^{67}$ A. Ostrowicz, Landek w hrabstwie Kłockiem w Szląsku. Podręcznik informacyjny dla gości kąpielowych, Poznań 1881.

${ }^{68}$ 0. Płachta, Uzdrowiskowa przestrzeń publiczna w wybranych miejscowościach Dolnego Śląska, , Studia Miejskie”, 16, 2014, s. 75-85.

${ }^{69}$ S. Bełza, W Górach Olbrzymich, Kraków 1898.
}

(1845), Henryk Wieniawski $(1855,1857)$ czy Ludwik Zamenhof (1901). Duszniki-Zdrój rozsławili natomiast Fryderyk Chopin (1826), Józef Elsner (1818), Franciszek Skarbek (1818), Zygmunt Krasiński (1829), Adolf Dygasiński (1881) i Ludwik Zamenhof $(1907)^{70}$.

Pierwsze obszerniejsze opisy uzdrowisk pojawiły się dopiero w XIX w., ale już w 1777 r. wydano przewodnik Johanna Gotfrieda Morgenbessera Publiczne Uwiadomienie Zdroiów Zdrowych lub wód mineralnych leczacych na Ślasku w Kodowie, Reynercu, Altwasser, Szarlotenbrun, Salcbrun $i$ Flinsbergu się znaydujących $\mathrm{w}$ polskim przekładzie Davida Vogla ${ }^{71}$. W XIX w. kuracjusze i turyści mogli korzystać np. z Wód Mineralnych Szlaskich i Hrabstwa Glackiego Karla Friedricha Moscha w przekładzie Alexandra Kuszańskiego ${ }^{72}$, Przewodnika dla pijacych wody mineralne Józefa Domaszewskiego $^{73}$, publikacji Józefa Orkisza pt. Zdroje lekarskie w Salzbrunn i Szczawnicy między soba porównat i skuteczność w chorobach piersiowych wykazat ${ }^{74}$, Przewodnika dla pijacych wody mineralne oraz sposobu zachowania sie podczas picia tychże Antoniego Stanisława Bergera ${ }^{75}$, dwu publikacji Michała Zieleniewskiego: Rysu balneologii powszechnej oraz Rysu balneotechniki na użytek wtaścicieli $i$ zarząów zdrojowisk tudziez lekarzy zdrojowych ${ }^{76}$, Poradnika dla pijacych wody w kazdym czasie Stelli Saxe w polskim przekładzie G. ${ }^{77}$, następnie

\footnotetext{
${ }_{70}$ A. Marek, Historia.

71 J.G. Morgenbesser, Publiczne Uwiadomienie Zdroiów Zdrowych lub wód mineralnych leczących na Śląsku w Kodowie, Reynercu, Altwasser, Szarlotenbrun, Salcbrun i Flinsbergu się znaydujących, ttum. D. Vogel, Wrocław 1777.

72 K.F. Mosch, Wody mineralne Szląskie i Hrabstwa Glackiego. Z przyłączeniem opisu Krzeszowic, ttum. A. Kuszański, Wrocław 1821.

${ }_{73}$ J. Domaszewski, Przewodnik dla pijących wody mineralne, Warszawa 1845.

74 J. Orkisz,Zdroje lekarskie w Salzbrunn i Szczawnicy między sobą porównat i skuteczność w chorobach piersiowych wykazat, Warszawa 1862.

${ }^{75}$ A.S. Berger, Przewodnik dla pijących wody mineralne oraz sposób zachowania się podczas picia tychże, Lwów 1876.

${ }^{76}$ M. Zieleniewski, Rys balneologii powszechnej, Warszawa 1873; tenże, Rys balneotechniki na użytek właścicieli i zarządów zdrojowisk tudzież lekarzy zdrojowych, Warszawa 1890.

77 S. Saxe, Poradnik dla pijących wody w każdym czasie, tłum. G., Warszawa 1877.
} 
Landku w hrabstwie Ktockiem w Szlasku. Podręcznika informacyjnego dla gości kapielowych Aleksandra Ostrowicza ${ }^{78}$, a także tekstów Kapiele w Reinerz (Duszniki). Uzdrowisko kuracyjne klimatyczne $w$ lasy bogate, 568 metrów ponad poziom morza wzniesione anonimowego autora ${ }^{79} \mathrm{czy} C \mathrm{Chu}$ doba (Cudowa). Klimatyczny zaktad zdrojowo leczniczy w górach z stawnemi stalowemi źródtami zawierającemi kwas weglowy, oraz kapielami stalowemi, gazowemi, ślamowemi, rosyjskiemi kapielami parowemi i tuszami wszelkiego rodzaju autorstwa Gottholda Scholza ${ }^{80}$.

Wiele informacji o sposobach leczenia i warunkach pobytu w zdrojowiskach zawierały listy pisane przez kuracjuszy. Hugona Kołłątaja interesowała głównie polityka, ale w jednym z pism z podróży zamieścił informację o dwóch zdrojach: „Alt-Wasser jest miejsce smutne i niemiłe, ale Warmbrunn bardzo przyjemne; pogody bardzo piękne [...]" ${ }^{\prime 1}$. Na tak przygnębiające wrażenie wpłynęły z pewnością kopalnie i huty funkcjonujące w okolicach Starego Zdroju, które powodowały tam deformację krajobrazu.

Walory uzdrowisk szeroko reklamowano i komentowano w niemieckiej i polskiej prasie $^{82}$. Przykładowo „Gazeta Warszawska” opublikowała w 1857 r. następujący opis uzdrowiska Salzbrunn:

„Któż z nas nie zna Salzbrunu? Kogóż choć raz w życiu przeznaczenie lub doktorowie nie wyprawili $\mathrm{w}$ to ustronie, w którym tak gwarno $\mathrm{z}$ rana, a tak cicho

\footnotetext{
${ }^{78}$ A. Ostrowicz, Landek.

${ }^{79}$ Kąpiele w Reinerz (Duszniki). Uzdrowisko kuracyjne klimatyczne w lasy bogate, 568 metrów ponad poziom morza wzniesione, Poznań 1894.

${ }^{80}$ G. Scholz, Chudoba (Cudowa). Klimatyczny zakład zdrojowo leczniczy w górach z sławnemi stalowemi źródłami zawierającemi kwas węglowy, oraz kąpielami stalowemi, gazowemi, ślamowemi, rosyjskiemi kąpielami parowemi i tuszami wszelkiego rodzaju, Poznań 1879.

${ }^{81}$ XIV List. Do J.P. Stanistawa Potockiego Jenerała Artyleryi konnéj, w: Listy Hugona Kottątaja pisane z emigracyi w r. 1792, 1793 i 1794, t. 1, oprac. L. Siemieński, Poznań 1872 (Pamiętniki Ośmnastego Wieku, 12), s. 17-18.

82 „Rozmaitości”, 19, 1838; „Dziennik Poznański”, 166, 1877; „,Dziennik Poznański”, 163, 1880; „Dziennik Poznański”, 145, 1895; „Dziennik Poznański”, 145, 1896; „,Tygodnik llustrowany”, 30, 1896; „,Kurier Warszawski”, 199, 1826; „Wędrowiec”, 35, 1883.
}

w południe, w którym ulata tyle gazu ze szklanek, ile westchnień miłosnych z piersi wybiega, czy tyle par, ile rozdziela koteryj, w którym plotki tak szybko biegają, jak wolno chodzą pacyenci. Skuteczność źródeł, piękność położenia, a nadewszystko blizkość od kraju naszego, iż miejsce to więcéj obejmuje żywiołu polskiego; prócz chorych - szukających zdrowia, panien - mężów, kawalerów - posagu, wiele jest osób, które przyjeżdżają tu bez celu, dla zabicia nudów, pokazania nowych toalet, a wszystko małym kosztem czasu i pieniędzy" ${ }^{83}$.

Zupełnie inne zdanie o Salzbrunnie miała natomiast anonimowa podróżniczka, która opublikowała zapiski ze swojego wyjazdu w „Dzienniku Literackim”: „Samo Salzbrunn nudne dla przybyłych, szczególniej w niedzielę jest nieznośnie; natłok, ścisk męczący, w całym tłumie oka nic nie zbawi, nie zajmie. [...] Okolice Salzbrunn posiada prześliczne" ${ }^{44}$.

Obraz funkcjonowania uzdrowiska Reinerz przedstawił w liście do przyjaciela Wilhelma Kolberga przebywający tam na kuracji zdrowotnej w 1826 r. Fryderyk Chopin. Zawarł w nim dość surową opinię o zdrojowej kapeli przygrywającej kuracjuszom: „Rano, najpóźniej o godzinie 6, już wszyscy chorzy przy źródle; tu dopiero nędzna dęta muzyka z kilkunastu karykatur w rozmaitym guście złożona, na czele których chudy fagocista, chudy, z osiodłanym, zatabaczonym nosem, przestraszający wszystkie damy, przygrywa wolno KurGästom" ${ }^{85}$. Listy Chopina są dziś cennym źródłem informacji o działaniu uzdrowiska i sposobie prowadzenia tam kuracji.

W połowie XIX w. w Sudety przybył człowiek wielu talentów - Bogusz Stęczyński. Można go określić jako krajoznawcę, poetę, malarza i grafika. Spostrzeżenia, ale również odczucia i wrażenia ze swoich

\footnotetext{
${ }^{83}$ L. Niemojewski, Listy Wędrowca. Salzbrunn, „Gazeta Warszawska”, 5 sierpnia 1857 , s. 4-5.

${ }^{84}$ Notatki z podróży, „Dziennik Literacki”, 24, 1864, s. 322-325.

${ }_{85}$ M. Karasowski, Fryderyk Chopin. Życie - listy - dzieła, t. 1, Warszawa 1882, s. 56.
} 
wędrówek opisywał w poematach, ilustrując walory przyrodnicze regionu licznymi grafikami. Podróż po Sudetach zaowocowała poematem Szlask ${ }^{86}$. Z uwagi na niechronologiczne przedstawienie odwiedzanych miejsc nie można na jego podstawie odtworzyć dokładnego przebiegu wędrówek, ale zawarte tam informacje same w sobie prezentują się dość ciekawie: „Oto w zmianie okolic wita nas $\mathrm{Cu}$ dowa, / Z położenia swojego przyjemna i zdrowa, / Zaszczyca się miłemi dziełami natury / Przez równiny piaszczyste i piaszczyste góry". Innym razem z entuzjazmem pisał o położeniu Kudowy: „Więc Cudowa bogata jest w dzieła przyrodzenia, / Godną jest odwiedzania, godną uwielbienia!"87.

Publicystka i autorka książek dla dzieci Julia z Molińskich Woykowska kurowała się po ciężkiej chorobie w Landku, a później w Kudowie. Pierwsze z tych miejsc określiła jako gwarne i gęsto zabudowane, „całkiem niemieckie”, drugie zaś charakteryzowała jako ciche, podobne do raju, zamieszkiwane przez ludność czeską ${ }^{88}$.

Warto podkreślić, że obok miejscowości znanych z leczniczego wykorzystywania wód powstały także stacje klimatyczne. Pierwszym tego rodzaju miejscem w Sudetach był Görbersdorf (ob. Sokołowsko), założony w 1854 r. przez niemieckiego ftyzjatrę Hermana Brehmera. Już w połowie XIX w. sądzono, że górskie powietrze ma pozytywny wpływ na zdrowie: „Góry otaczające Görbersdorf, w wysokości od 1000 stóp nad doliną, a do 3000 stóp nad powierzchnią morza, pokryte są gęstym lasem jodłowym, który nasyca powietrze ozonem, tak ważną rolę odgrywającym w sprawie odnowienia krwi i całego organizmu"89. Zalety Sokołowska reklamowane były w polskiej prasie. Anonimowy autor pisał np.: „Kto szuka wykwintu,

\footnotetext{
${ }_{86}$ Szląsk. Podróż malownicza.

87 Tamże. Zob. też: J. Reychman, Turystyka, s. 20-38.

${ }^{88}$ J. Woykowska, Z Kudowy, Poznań 1850.

${ }^{89}$ Dr Brehmer ijego zakład leczniczy dla chorych piersiowych w Görbersdorfie na Szlązku, „Kłosy”, 30 (773), 1880, s. 261-262.
}

blasku, wesołości, - niech się tam nie udaje na próżno; lecz kto chce zaczerpnąć całą piersią cudownego powietrza, napojonego wonią drzew iglastych, polnych kwiatów i łąk [...] - kto pragnie wypocząć ciałem i duchem w czarującéj samotni i ciszy tego z pewnością Görbersdorf zadowoli więcéj niż każda inna miejscowość" 90 . W „Tygodniku Ilustrowanym” z 1895 r. pojawiła się zaś wzmianka, że kuracja w stacji klimatycznej Görbersdorf nie odbiega od leczenia w takich ośrodkach jak Merano w Tyrolu i Davos w Szwajcarii ${ }^{91}$.

\section{Góry jako przestrzeń emocji i wrażeń}

Obok uzdrowisk zaczęła się kształtować turystyka górska - na początku śladowo $\mathrm{w}$ nielicznych regionach, ale z czasem rozpowszechniła się na całe Sudety. Pierwsze wpisy pozostawiane $\mathrm{w}$ kronikach nie zachęcały do górskich wypadów. Sądzono, że „wędrówki w góry nie służą rozkoszowaniu się przyjemnościami spaceru", uważając je za „przykre, odrażające i obrzydliwe” 92 .

Relacje pełne wrażeń pojawiły się natomiast we wspomnieniach senatora Królestwa Polskiego Józefa Morawskiego, który odwiedzał Sudety w 1815 r. Szczególnie zafascynowały go widoki, jakich dostarczała ziemia kłodzka: „Wjazd ten do miasteczka nad kręto płynącą rzeką Neisse położonego, sprawia przyiemny widok podróżnemu. [...]. Daléy wspaniały odkrywa się widok na całe Hrabstwo Glatzkie górami opasałe i na rozmaite doliny rzekami [...] poprzedzielane" ${ }^{93}$.

Bogaty opis karkonoskiego krajobrazu pojawił się również w dzienniku Izabeli Czartoryskiej. Wiele uwagi poświęciła zwyczajom panującym u wód, ale w jej relacji nie brakuje również wrażeń estetycznych: „Nie umiem powiedzieć, co się działo ze

\footnotetext{
${ }^{90}$ E.H., Zakład leczniczy w Görbersdorfie, „Tygodnik Ilustrowany”, 392, 1875, s. 8-9.

${ }_{91}$ Görbersdorf, ,Tygodnik llustrowany", 38, 1895, s. 190.

${ }_{92}$ Z. Kulik, Wędrówki, s. 79-92.

93 J. Morawski, Podróż w Śląsk w roku 1815 opisana w listach do brata, „Pamiętnik Warszawski”, 4, 1816, s. 247.
} 
mną u stóp wodospadu wśród olbrzymich skał. Widok pięknej przyrody zwraca zawsze myśl moją ku Bogu; zapominam przez chwilę, gdzie jestem, wydaje mi się, że przebywam w jakimś świecie idealnym i jestem przekonana, że gdybym nie wylała z emocji kilku łez - udusiłabym się" ${ }^{\text {" }}$. Czartoryska wielokrotnie zwracała uwage na harmonię życia. W wielu akapitach pojawiają się takie określenia, jak „oszołomieni wspaniałym widokiem”, „z zachwytem obejrzałam ten piękny zakątek”, „odeszłam głęboko wzruszona”.

W 1822 r. historyk Fryderyk Skarbek, odbywając podróż przez Śląsk, dotarł do Warmbrunnu. Zapytany o jej cel, odparł: „[...] chcę śledzić tych znamion piękności, któremi twórca wszystkie dzieła swoie naznaczył, i pokrzepiać ciągle umysł widokiem dobrego i pięknego"95.

Okolice Cieplic zyskały wśród turystów większą rangę po wydaniu pierwszego polskojęzycznego przewodnika - Warmbrunn i okolice jego $w 38$ obrazach $w 12$ tu wycieczkach przez pielgrzymke w Sudetach, napisanego w 1850 r. przez Rozalię Saulsonową ${ }^{96}$.

Ciekawym przykładem reminiscencji jest opis pobytu w Reinerzu zamieszczony przez Chopina w adresowanym Kolberga liście z 18 sierpnia 1826 r. Oprócz ścisłych reguł kuracji kompozytor przedstawił swoje wrażenia z wycieczek po okolicy: „Chodzę ja wprawdzie po górach, któremi Reinertz otoczon; często zachwycony widokiem tutejszych dolin z niechęcią złażę, czasem na czworakach, alem jeszcze nie był tam, gdzie wszyscy jadą, bo mi zakazano. Jest tu w bliskości Reinertz góra ze skałami zwana Heuscheuer [Szczeliniec 919 m n.p.m.] miejsce, z którego widoki zachwycające, ale dla niezdrowego powietrza na samym wierzchołku nie wszystkim

\footnotetext{
${ }^{94}$ I. Czartoryska, Dyliżansem przez Śląsk. Dziennik podróży do Cieplic w roku 1816, przekł., wstęp i oprac. J. Bujańska, Wrocław 2006.

${ }^{95}$ F. Skarbek, Podróż bez celu, Warszawa 1824, s. 126.

${ }^{96}$ R. Saulson, Warmbrunn i okolice jego w 38 obrazach w 12tu wycieczkach przez pielgrzymke w Sudetach, Wroctaw 1850.
}

dostępna, a ja jestem jednym z tych pacjentów, na nieszczęście, którym tam nie wolno" 97 . W tym samym piśmie wspominał, że planuje osiągnąć inny szczyt: „Wybieramy się na jakieś Hohemenze [Orlicę - 1084 m n.p.m.], ma to być też góra w przepysznej okolicy; spodziewam się, że przyjdzie do skutku" ${ }^{98}$. Choć goście dusznickiego uzdrowiska zachwycali się Szczelińcem i stanowił on popularny cel wędrówek kuracjuszy, to jednak zdrojowi lekarze mieli o nim zupełne inne zdanie.

Wyjazdy w celach zdrowotnych spopularyzowały turystykę górską, ona zaś stała się dodatkowym, ale i nierozłącznym elementem urozmaicającym pobyt w uzdrowiskach. Kuracjusze odwiedzali położone w pobliżu zdrojów wzniesienia, by ekscytować się lokalnymi krajobrazami.

W 1838 r. na łamach czasopisma „Zbieracz Literacki” opublikowane zostały wspomnienia Karola Antoniewicza, który rok wcześniej odbył wędrówkę po okolicach Reinerzu. Zachwycony widokami, pisał: „Ze wszystkich strón cudny otaczał nas krajowid. Góry, nic jak tylko góry! Nie jednemu ciagły widok gór, jednostajnym, a opisanie ich nudném wydawać się może. Lecz kto w pośrodku nich się rodził i wychował, kto tych niemych świadków najszczęśliwszych lat życia pokochał, kto wewnętrzne życie tych przedpotopnych olbrzymów zgłębić usiłował, a przed ich wielkością ugiął kolana i ducha upokorzył, w uczuciu miłości i wdzięczności ku Temu, który je na twardych granitowych posadzał podstawach; temu widok ich obojętnym być nié może" 99 .

Podczas pobytu w Reinerzu Antoniewicz postanowił wyruszyć w Góry Stołowe, by zobaczyć skalne cuda natury, o których często dyskutowali kuracjusze:

\footnotetext{
${ }_{97}$ F. Chopin, Do Wilhelma Kolberga w Warszawie, Reinertz [Duszniki], 18 sierpnia [1826], „Narodowy Instytut Fryderyka Chopina” (https://pl.chopin nifc.pl/chopin/letters/detail/page/2/id/437, dostęp: 4 lipca 2020).

${ }^{98}$ Tamże.

${ }^{99}$ K. Antoniewicz, Wspomnienia z wędrówki przez Góry Olbrzymie (Riesengebirge) w roku 1837, „Zbiéracz Literacki”, 3 (14), 1838, s. 105.
} 
„Długo przypatrywaliśmy się z podziwieniem, dojeżdżając już do Karlsberg, tym w dziwaczne kształty tak groźnie napiętrzonym skałom, które jakby chmury wiatrem pędzone, przy różnych wykrętach drogi odmienną zdawały się przybierać postać [...]"100. Okolicę górską przedstawiał zaś następująco: „O, jak ta czarująca okolica, słabym promieniem księżyca oświécona, do duszy mojéj przemawiała" ${ }^{101}$.

Lekarz Fryderyk Skobel pisał z kolei: „Kto ma upodobanie w widokach dzikich, mianowicie w dziwacznych postaciach piaskowca, od wieków kruszonego i drążonego rozmaicie, od skwaru słońca, od mrozu, od powietrza i wody, ten będąc w Chudobie, może się do sytu rozpatrzyć tym wybrykom rody” ${ }^{102}$; „Komu pozwalają siły, ten znajdzie niejedną przyjemność w wycieczkach do różnych miejsc pobliskich i dalszych, wabiących już-to pięknym, już-to przynajmniej osobliwym widokiem albo wspomnieniem dziejowem" ${ }^{103}$. Innym razem wspomniał, że wyprawy te podejmował „dla pięknego widoku na okolice $[. .] "$.104 .

Wspomniany już Stęczyński niezwykle szeroko podkreślał w swoim poemacie Szląsk różnorodne wątki, które wzajemnie się uzupełniały. Miał bardzo rozległa wiedzę o odwiedzanym regionie, miejscowościach i osobliwościach przyrody. Często łączył więc treści historyczne, patriotyczne, religijne, społeczne, gospodarcze i przyrodnicze. Ważne miejsce zajmowały w jego tekście legendy i podania, ale także emocje: „W paśmie Jeleniej Góry, zwidzając parowy, / Doznajemy obawy i zawrotu głowy, / Ale ciekawość nasza

\footnotetext{
100 Tenże, Wspomnienia z wędrówki przez Góry Olbrzymie w roku 1837, „Rozmaitości” [pismo dodatkowe do „Gazety Lwowskiej”], 31, 1838, s. 245.

${ }_{101}$ Tenże, Wspomnienia z wędrówki przez Góry Olbrzymie w roku 1837, „Rozmaitości” [pismo dodatkowe do „Gazety Lwowskiej”], 5, 1838, s. 37.

102 F. Skobel, Chudoba (po niemiecku: Kudowa). Wspomnienie z podróży odbytej do zdrojowisk Szląskich, „Wieniec. Pismo zbiorowe ofiarowane Stanisławowi Jachowiczowi przez pierwszych kraju autorów oraz licznych jego przyjaciół i wielbicieli", 1, 1857, s. 425.

103 Tamże, s. 424

104 Tamże.
}

trudności przemaga, / A umacniawytrwałość, ochota, odwaga" 105 .

Romantyczna górska kraina zachwycała różnorodnymi wytworami przyrody, zamkami, ruinami i wieloma romantycznymi budowlami. Euforia podczas pierwszych wyjazdów napawała do kolejnych wizyt w Sudetach. Niekiedy podziwiany krajobraz łączony był ze sferą sacrum. W wielu publikacjach pojawia się duch religijny. Przebywający w 1855 r. w Szczawnie Józef Korzeniowski, opisując panujące w uzdrowisku relacje, pokusił się o następującą refleksję: „Kto po raz pierwszy z miejsca tego rzuci okiem w około, uczuje się aż nadto wynagrodzonym za trud nużącéj cokolwiek przechadzki, podniesie się myślą do Twórcy, który tak cudną rozmaitością zakąt ten ziemi ubogacił, i pozazdrości ludowi, który tam osiadł [...]"106. Interesująco motywował swoją wycieczkę Stanisław Bełza: „A oto jedziemy w góry, odetchnać świeżem powietrzem, ogarnąć okiem szeroki widnokrąg, ukorzyć się przed potęgą Boga" ${ }^{107}$.

\section{Obiekty antropogeniczne jako przestrzeń emocji i wrażeń}

Wielokrotnie zachwyt odwiedzających budziły śląskie zamki. W relacji Antoniewicza, który podróżował przez Śląsk w 1837 r., pojawia się zamek Fürstenstein (Książ): „O jak odmienne wrażenie sprawia widok zamku starożytnego, a tego miejsca tak złudnie urządzonego! Tam z każdego kamienia, z każdéj cegiełki wyłamanéj, omszonéj, prawda silnie do duszy przemawia i w dawne przenosi ją wieki [...]"; „Czarujący widok zachwycił nas z galeryi zamku nowego" 108 .

Fascynacja romantycznymi ruinami zamku Kynast (Chojnik) na tle pejzażu Karkonoszy pojawiła się w publikacji

\footnotetext{
105 Szląsk. Podróż malownicza, s. 58.

${ }^{106} J$ J. Korzeniowski, Spotkanie w Salzbrun, w: Dzieła Józefa Korzeniowskiego, t. 7. Warszawa 1872, s. 449.

107 S. Bełza, W Górach Olbrzymich, s. 6-7.

108 K. Antoniewicz, Wspomnienia z wędrówki przez Góry Olbrzymie w roku 1837, „Rozmaitości”, 5, 1838, s. 38.
} 
Teresy Wodzickiej: „Wielka rozmaitość krajobrazu, natura majestatyczna z romantyczno-malowniczemi efektami”"109.

W XIX w. turyści zaczęli kierować pierwsze kroki do podziemnych obiektów górniczych i jaskiń. Co ciekawe, wycieczki w takie miejsca organizowano w lądeckim uzdrowisku. Obiektem zainteresowania kuracjuszy stały się kamieniołomy na stoku Krzyżnika w okolicach Stronia Śląskiego (Seitenberg): „Wkrótce całe towarzystwo znalazło się u wejścia do kopalni. Otwór jej miał kształt komnaty tytanicznych rozmiarów, wyrąbanej w skale; ściany olśniewającej białości, rumieniły się miejscami krwawemi żyłkami. [...] W głębi komnaty, po lewej stronie była pieczara, do której wejścia strzegł wiszący nad nią zrąb marmuru zaostrzony nakształt topora [...]. $\mathrm{Z}$ pieczary tej wypływała woda. [...] Czerwone żyły marmuru zdawały się drgać" ${ }^{110}$.

W literaturze pojawiły się również pierwsze opisy obiektów przemysłowych, jak sztolnie czy kopalnie. W XIX w. zaczęto organizować wycieczki do tego rodzaju podziemnych obiektów, w tym Lisiej Sztolni (ryc. 4), w specjalnie przygotowanych strojach górniczych. Wrażeniami ze zwiedzania sztolni dzieliła się księżna Czartoryska: „Zrobiliśmy uroczą wycieczkę; siostra pani Kospott jest żoną pana Mielińskiego, polskiego szlachcica, dyrektora kopalni węgla, urządzonych według angielskiego systemu. Miałam wielką ochotę zobaczyć je i w dniu dzisiejszym właśnie pozwolono nam tam iść. Pan Mieliński przyjął nas u wejścia; weszliśmy do barki - było nas razem dwanaście osób. Płynęliśmy strumieniem czy podziemnym kanałem [...]. Wszystko było rzęsiście oświetlone, poprzedzała nas piękna muzyka na innej barce. Po przybyciu do kopalni [...] znaleźliśmy bardzo piękny salon. Wszystko było umajone zielenią i rzęsiście iluminowane. W głębi transparent przywitał nas słowami,

\footnotetext{
109 T. Wodzicka, Ze zwierzeń dziewczęcych. Pamiętnik Zofii z Matuszewiczów Kickiej 1796-1822, Kraków 1910.

110 Z. Urbanowska, Cudzoziemiec, Warszawa 1912, s. 110.
}

którymi górnicy pozdrawiają zawsze tych, których ujrzą lub spotkają; są to dwa słowa: "Szczęść Boże«, co jest równoznaczne z życzeniem: "wróć stąd szczęśliwie i bezpiecznie«. Wysiedliśmy w salonie i zjedliśmy z apetytem podwieczorek. Byliśmy 200 sążni pod ziemią, rzęsiście oświetleni, otoczeni kwiatami, i wróciliśmy wesoło przy dźwiękach obojów i klarnetów, wyraziwszy wdzięczność aranżerom tej pięknej wyprawy" 111 .

W opisie Maurycego Karasowskiego pojawiła się z kolei wzmianka o kopalni w Altwasserze i możliwości jej zwiedzania: „[...] chętnie odwiedzają to miłe i zajmujące miejsce, a ciekawsi wstępują do giserni lub zwiedzają leżące na drodze kopalnię węgla kamiennego, gdzie dowcipnie urządzona parowa machina wyciąga z głębi 180 stóp pod ziemią ów materiał, będący najgłówniejszym czynnikiem i podstawą dobrego bytu tutejszych przemysłowych mieszkańców. Szyby kopalni rozciągają się niesłychanie szeroko, zwiedzanie ich jest wielce ciekawe, ale niezupełnie bezpieczne, było jednakże w zeszłym miesiącu dwóch śmiałych młodzieńców, którzy nie ulękli się ciemności, wody i duszącego powietrza, częścią zgięci we dwoje, częściej na czworakach, z kilku tylko co chwila gasnącymi latareczkami spuściwszy się w Altwasser, w kilka godzin takiej podziemnej wędrówki przybyli do Salzbrunn, gdzie także jeden z otworów się znajduje"112.

\section{Podsumowanie}

Odkrywanie Sudetów przez stulecia miało bardzo różnorodny charakter. Pionierskie wędrówki w góry zupełnie odbiegały od podróży odbywanych w XVIII i XIX w. przez turystów i kuracjuszy. Początkowo góry budziły wśród miejscowej ludności respekt i strach, a wyobrażenia o nich zawierały pierwiastek demoniczności. Z czasem zaczęło się stopniowe oswajanie

\footnotetext{
111 I. Czartoryska, Dyliżansem

112 [M. Karasowski], Listy z podróży. Salzbrunn dnia 16 lipca 1858 roku, „Kronika Wiadomości Krajowych i Zagranicznych”, 3 (193), 1858, s. 4.
} 


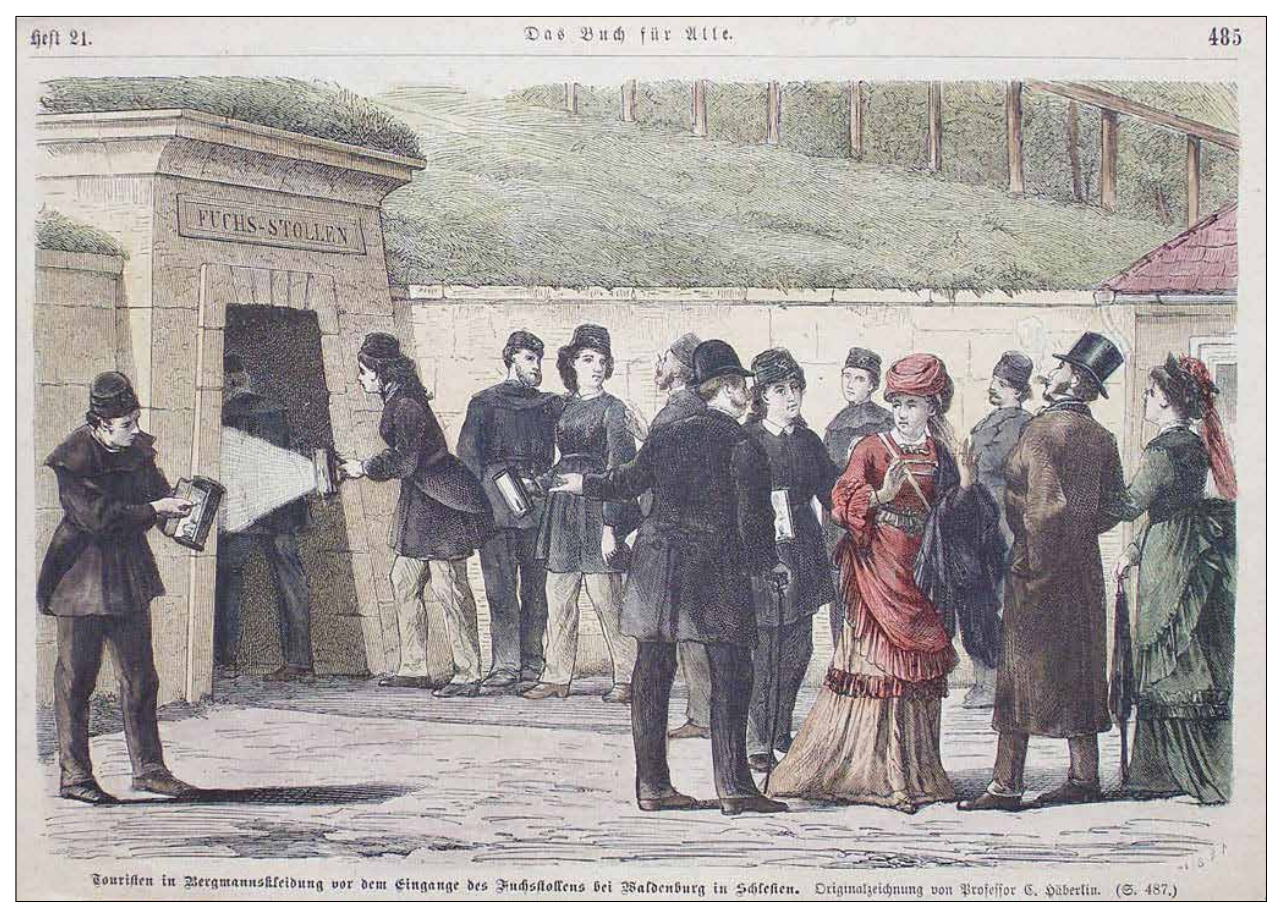

Ryc. 4. C. Häberlin, „Turyści przed wejściem do Lisiej Sztolni”, rysunek w: „Das Buch für Alle. Illustrirte Blätter zur Unterhaltung und Belehrung. Für die Familie und Jedermann", Stuttgart 1876.

Źródto: „Polska-org” (https://polska-org.pl/937843,foto.html?idEntity=549584, dostęp: 4 lipca 2020)

ich przestrzeni poprzez działalność gospodarczą: górnictwo, hutnictwo, szklarstwo, zbieractwo ziól, pasterstwo itp.

W Sudetach dużą rolę pełniły położone u stóp gór uzdrowiska. Gwarne zdroje, których największy rozkwit przypadał na przełom XVIII i XIX w., szybko przestały wystarczać pragnącym rozrywek kuracjuszom, dlatego zaczęli oni szukać wrażeń dalej, wędrując po okolicach i poznając krajobraz. To właśnie oni byli więc pierwszymi turystami górskimi.

Wycieczki podejmowano często $\mathrm{w}$ poszukiwaniu romantycznych uniesień, dla wzbudzenia emocji i przeżyć. We wspomnieniach publikowanych na łamach
XIX-wiecznej polskiej prasy można zauważyć, jak wielką rolę odgrywała w tych peregrynacjach sfera duchowa. Bohaterowie relacji szczegółowo opisywali oglądany górski pejzaż oraz emocje, które towarzyszyły im podczas wędrówek. Romantyzm i sentymentalizm były dominującymi aspektami opisywanych przez nich przeżyć. Jak pisał Wiesław Ring, to właśnie w Sudetach „Polacy uczyli się turystyki i krajoznawstwa, przenosząc je później w Tatry"113.

${ }^{113}$ W. Ring, Z dziejów przewodnictwa turystycznego w Polsce, w: Przewodnictwo turystyczne w Polsce, Warszawa-Kraków 1986, s. 23-43. 


\section{Bibliografia}

Andrejew A., Kaspar Schwenckfeldt - renesansowy badacz przyrody karkonoskiej, „Rocznik Jeleniogórski”, 19, 1981.

Andrejew A., Trasy wędrówek krajoznawczo-naukowych Kaspra Schwenckfeldta po Sudetach Zachodnich, „Wierchy”, 61, 1995.

Antoniewicz K., Wspomnienia z wędrówki przez Góry Olbrzymie (Riesengebirge) w roku 1837, „Rozmaitości” [pismo dodatkowe do „Gazety Lwowskiej”], 5, 1838.

Antoniewicz K., Wspomnienia z wędrówki przez Góry Olbrzymie (Riesengebirge) w roku 1837, „Rozmaitości” [pismo dodatkowe do „Gazety Lwowskiej”], 7, 1838.

Antoniewicz K., Wspomnienia z wędrówki przez Góry Olbrzymie (Riesengebirge) w roku 1837, „Rozmaitości” [pismo dodatkowe do „Gazety Lwowskiej”], 31, 1838.

Antoniewicz K., Wspomnienia z wędrówki przez Góry Olbrzymie (Riesengebirge) w roku 1837, „Zbiéracz Literacki”, 3 (14), 1838.

Bartoš M., Klimeš P., Louda J., Nejstarši obrazová mapa Krkonoš, Vrchlabí 2012.

Bełza S., W Górach Olbrzymich, Kraków 1898.

Berger A.S., Przewodnik dla pijacych wody mineralne oraz sposób zachowania się podczas picia tychże, Lwów 1876.

Chopin F., Do Wilhelma Kolberga $w$ Warszawie, Reinertz [Duszniki], 18 sierpnia [1826], „Narodowy Instytut Fryderyka Chopina” (https://pl.chopin. nifc.pl/chopin/letters/detail/page/2/id/437, dostęp: 4 lipca 2020).

Ciężkowski W., Szwarc J., Śnieżnik. Dzieje zagospodarowania szczytu, „Pielgrzymy”, 1986.

Czartoryska I., Dylizansem przez Ślask. Dziennik podróży do Cieplic w roku 1816, przekł., wstęp i oprac. J. Bujańska, Wrocław 2006.

Domaszewski J., Przewodnik dla pijacych wody mineralne, Warszawa 1845.

Domosławski Z., Medycyna górska, w: Karkonosze polskie, red. A. Jahn, Wrocław-Warszawa-KrakówGdańsk-Łódź 1985.

Dr Brehmer i jego zaktad leczniczy dla chorych piersiowych w Görbersdorfie na Szlazku, „Kłosy”, 773, 1880.

Dziedzic M., Ktodzkie Towarzystwo Górskie 18811945, Wrocław 2013.

Dzieta Józefa Korzeniowskiego, t. 7, Warszawa 1872.

E.H., Zaktad leczniczy w Görbersdorfie, „Tygodnik Ilustrowany", 392, 1875.

Gaj J., Dzieje turystyki w Polsce, Warszawa 2008.

Gaj J., Zarys historii turystyki w Polsce, Warszawa 2003.

Gaj J., Zarys historii turystyki w Polsce w XIX i XX wieku, Poznań 2001.
Görbersdorf, „Tygodnik Ilustrowany”, 38, 1895.

Góry Stołowe. Stownik geografii turystycznej Sudetów, t. 13, red. M. Staffa, Warszawa-Kraków 1992.

Häberlin C., Turyści przed wejściem do Lisiej Sztolni, rysunek w: Das Buch für Alle. Illustrirte Blätter zur Unterhaltung und Belehrung. Für die Familie und Jedermann, Stuttgart 1876 (https://polska-org.pl/ 937843, foto.html?idEntity=549584, dostęp: 4 lipca 2020).

Hájek V. z Libočan, Kronika česká, [t.] 4: Čechy královské. R. 1254-1347, Praha 1933.

Hempel K., $Z$ dziejów zielarstwa $w$ Sudetach, „Wierchy", 27, 1958.

Janczak J., Z dziejów turystyki śląskiej w XIX i pierwszej potowie XX stulecia, w: I Ślaskie Sympozjum Krajoznawców, red. T.J. Rogoża, Opole 1977.

Janczak J., Z kuferkiem i chlebakiem, WarszawaKraków 1988.

Jaworski K., Turystyka polska w czeskich Sudetach w XVIII $i$ XIX wieku, ,Acta Universitatis Wratislaviensis", 2055 (3), 1998.

Karasowski M., Fryderyk Chopin. Życie - listy - dzieta, t. 1, Warszawa 1882.

[Karasowski M.], Listy z podróży. Salzbrunn dnia 16 lipca 1858 roku, „Kronika Wiadomości Krajowych i Zagranicznych”, 3 (193), 1858.

Karkonosze polskie, red. A. Jahn, Wrocław-WarszawaKraków-Gdańsk-Łódź 1985.

Karkonosze. Przyroda nieożywiona i cztowiek, red. M.P. Mierzejewski, Wrocław 2005.

Kapiele w Reinerz (Duszniki). Uzdrowisko kuracyjne klimatyczne $w$ lasy bogate, 568 metrów ponad poziom morza wzniesione, Poznań 1894.

Kincel R., Początki przewodnictwa turystycznego w Karkonoszach, Jelenia Góra 1972.

Kincel R., Początki turystyki i przewodnictwa turystycznego na Ziemi Ktodzkiej, w: V Forum Krajoznawstwa Dolnoślaskiego, Polanica-Zdrój 1976.

Kincel R., Sarmaci na Śnieżce, Wrocław 1973.

Kincel R., U szlaskich wód, Racibórz 1994.

Kolbuszewski J., Kilka uwag o dawnych wycieczkach na Śnieżkę w Karkonoszach, „Góry, Literatura, Kultura”, 11, 2018.

Kolbuszewski J., Krajobraz i kultura, Katowice 1985.

Kolbuszewski J., Najdawniejszy polski przewodnik po Karkonoszach, „Wierchy”, 48, 1979.

Kolbuszewski J., Rozalii rady i wskazówki (O najdawniejszym polskim przewodniku górskim), „Rocznik Jeleniogórski”, 18, 1980.

Kolbuszewski J., Z dziejów Śnieżki w Karkonoszach, Warszawa-Kraków 1990.

Komarnicki Z., Kronika Marcina Galla przetożona na język polski i objaśniona, Warszawa 1873. 
Konopczyński W., Opis Wroctawia i Cieplic z XVII wieku, „Sobótka”, 3, 1948.

Korzeniowski J., Spotkanie w Salzbrun, w: Dzieta Józefa Korzeniowskiego, t. 7, Warszawa 1872.

Kosiński W., Setkowicz B., Trojanowski J., Zagospodarowanie Śnieżnika, „Wierchy”, 49, 1980.

Krygowski W., Zarys dziejów polskiej turystyki górskiej, Warszawa 1973.

Kulczycki Z., Zarys historii turystyki w Polsce, Warszawa 1977.

Kulik Z., Historia poznania gór, w: Karkonosze polskie, red. A. Jahn, Wrocław-Warszawa-KrakówGdańsk-Łódź 1985.

Kulik Z., Wędrówki na Śnieżkę w I potowie XVIII wieku, „Rocznik Jeleniogórski”, 16, 1978.

Kultura i turystyka. Sacrum i profanum, red. J. Mokras-Grabowska, J. Latosińska, Łódź 2016.

Lewan M., Zarys dziejów turystyki w Polsce, Kraków 2004.

Listy Hugona Kottątaja pisane z emigracyi w r. 1792, 1793 i 1794, t. 1, oprac. L. Siemieński, Poznań 1872 (Pamiętniki Ośmnastego Wieku, 12).

Łaborewicz I., Co nowego wiemy o Rozalii Saulson i jej pobycie w Cieplicach Ślaskich-Zdroju?, „Wierchy”, 65, 1999.

Łazarek M., Łazarek R., Śladami historii turystyki. Od starożytności do wspótczesności, Lublin 2005.

Marek A., Historia turystyki, w: Sudety i Przedgórze Sudeckie. Środowisko, ludność, gospodarka, red. A. Marek, I.J. Olszak, Wrocław 2014.

Marek A., Olszak I.J., Potożenie Sudetów, jednostki fizyczno-geograficzne, w: Sudety i Przedgórze Sudeckie. Środowisko, ludność, gospodarka, red. A. Marek, I.J. Olszak, Wrocław 2014.

Mazurski K.R., Geografia turystyczna Sudetów, Wroclaw 2003.

Mazurski K.R., Historia turystyki sudeckiej, Kraków 2012.

Mazurski K.R., Lwiniec i Świeradów Zdrój, „Informator Krajoznawczy”, 3-4, 1984.

Michniewicz Z., Szkic dziejów turystyki ślaskiej w Karkonoszach, „Rocznik Wrocławski”, 3-4, 1959-1960.

Michniewicz Z., Z dziejów turystyki polskiej w Karkonoszach (na początku XIX wieku), „Wierchy”, 25, 1956.

Morawski J., Podróż $w$ Ślask w roku 1815 opisana $w$ listach do brata, „Pamiętnik Warszawski”, 4, 1816.

Morgenbesser J.G., Publiczne Uwiadomienie Zdroiów Zdrowych lub wód mineralnych leczacych na Ślasku $w$ Kodowie, Reynercu, Altwasser, Szarlotenbrun, Salcbrun i Flinsbergu się znaydujacych, tłum. D. Vogel, Wrocław 1777.

Mosch K.F., Wody mineralne Szlaskie i Hrabstwa Glackiego. Z przytaczeniem opisu Krzeszowic, tłum. A. Kuszański, Wrocław 1821.

Niemojewski L., Listy Wędrowca. Salzbrunn, „Gazeta Warszawska”, 5 sierpnia 1857.
Notatki z podróży, „Dziennik Literacki”, 24, 1864.

Odyniec W., Z dziejów polskiej turystyki od XVI wieku do roku 1939, Gdańsk 1993.

Orkisz J., Zdroje lekarskie w Salzbrunn i Szczawnicy między soba porównat i skuteczność w chorobach piersiowych wykazat, Warszawa 1862.

Osowska A., Sudety na dawnych mapach, w: Sudety i Przedgórze Sudeckie. Środowisko, ludność, gospodarka, red. A. Marek, I.J. Olszak, Wrocław 2014.

Ostrowicz A., Landek w hrabstwie Ktockiem w Szlasku. Podręcznik informacyjny dla gości kapielowych, Poznań 1881.

Pabel F., Krótka historia uprzystępnienia Szczelińca, tłum. Z. Gdowski, oprac. T. Dudziak, „Pielgrzymy", 1988.

Pełech T., Hannibal ante portas. Interpretacja fabuty z 21 rozdziatu III ksiegi Kroniki polskiej Anonima tzw. Galla, „Meluzyna. Dawna Literatura i Kultura”, 1 (4), 2016.

[Piąte] V Forum Krajoznawstwa Dolnoślaskiego, Polanica-Zdrój 1976.

[Pierwsze] I Ślaskie Sympozjum Krajoznawców, red. T.J. Rogoża, Opole 1977.

Płachta O., Uzdrowiskowa przestrzeń publiczna w wybranych miejscowościach Dolnego Ślaska, „Studia Miejskie”, 16, 2014.

Potocki J., Funkcje turystyki w ksztattowaniu transgranicznego regionu górskiego Sudetów, Wrocław 2009.

Potocki J., Rozwój zagospodarowania turystycznego Sudetów od potowy XIX wieku do II wojny światowej, Jelenia Góra 2004.

Potocki J., Śnieżka jako cel wędrówek i miejsce kultu religijnego, w: Kultura i turystyka. Sacrum i profanum, red. J. Mokras-Grabowska, J. Latosińska, Łódź 2016, s. 101-115.

Potocki J., Dudziak T., Zarys dziejów znakowania szlaków turystycznych $w$ Sudetach, w: Szlaki turystyczne a przestrzeń turystyczna, red. P. Kuleczka, Warszawa 2007.

Przerwa T., Odkryli dla nas piękno gór, Toruń 2003.

Przerwa T., Organizacje turystyczne na Ziemi Ktodzkiej do 1945 r. Zarys problematyki badawczej, „Kládský sborník", 5, 2003.

Przerwa T., Wędrówka po Sudetach. Szkice z historii turystyki ślaskiej przed 1945 r., Wrocław 2005.

Przewodnictwo turystyczne w Polsce, Warszawa-Kraków 1986.

Reychman J., Turystyka polska do 1945 roku, „Wierchy”, 40, 1971.

Ring W., $Z$ dziejów przewodnictwa turystycznego w Polsce, w: Przewodnictwo turystyczne w Polsce, Warszawa-Kraków 1986.

Růžička J., Jordáková J., Pozlovská Z., Skalni města do kapsy, Praha 2006. 
Rzepczyński R., Historia podboju królestwa Ducha Gór, czyli szkic z dziejów turystyki u stóp Śnieżki (cz. 1), „Rocznik Jeleniogórski”, 29, 1997.

Saulson R., Warmbrunn i okolice jego w 38 obrazach w 12tu wycieczkach przez pielgrzymkę $w$ Sudetach, Wrocław 1850.

Saxe S., Poradnik dla pijących wody w każdym czasie, tłum. G., Warszawa 1877.

Scholz G., Chudoba (Cudowa). Klimatyczny zaktad zdrojowo leczniczy $w$ górach z stawnemi stalowemi źródtami zawierającemi kwas weglowy, oraz kapielami stalowemi, gazowemi, ślamowemi, rosyjskiemi kapielami parowemi i tuszami wszelkiego rodzaju, Poznań 1879.

Skarbek F., Podróż bez celu, Warszawa 1824.

Skobel F., Chudoba (po niemiecku: Kudowa). Wspomnienie z podróży odbytej do zdrojowisk Szlaskich, „Wieniec. Pismo zbiorowe ofiarowane Stanisławowi Jachowiczowi przez pierwszych kraju autorów oraz licznych jego przyjaciół i wielbicieli”, 1, 1857.

Staffa M., Historia poznania Karkonoszy oraz rozwój osadnictwa, w: Karkonosze. Przyroda nieożywiona i człowiek, red. M.P. Mierzejewski, Wrocław 2005.

Staffa M., Karkonosze, Wrocław 2001.

Staszewski J., Mappa mundi z Ebstorfu jako źródto wiedzy geograficznej średniowiecza, „Przegląd Geograficzny”, 38 (2), 1966.

Staszic S., O ziemiorództwie Karpatów i innych gór i równin Polski, Warszawa 1815.

Steć T., Przyczynki do dziejów turystyki w Karkonoszach, „Wierchy”, 24, 1955.
Steć T., Walczak W., Karkonosze - monografia krajoznawcza, Warszawa 1962.

Sudety i Przedgórze Sudeckie. Środowisko, ludność, gospodarka, red. A. Marek, I.J. Olszak, Wrocław 2014.

Szczepankiewicz-Battek J., Zbór Braci Czeskich w Górach Stotowych, „Pielgrzymy”, 1997.

Szczepański E., Z dziejów karkonoskich schronisk (Samotnia), „Rocznik Jeleniogórski”, 16, 1978.

Szlaki turystyczne a przestrzeń turystyczna, red. P. Kuleczka, Warszawa 2007.

Szląs. Podróż malownicza, w 25-ciu pieśniach wyśpiewat Bogusz Zygmunt Stęczyński, Wrocław 1851, rkps, Zakład Narodowy im. Ossolińskich, sygn. 3424/I.

Świerz M., Zarys dziejów taternictwa polskiego, „Pamiętnik Towarzystwa Tatrzańskiego", 34, 1913.

Tyblewski T., Rola przewodników turystycznych $w$ wychowaniu, Warszawa 1979.

Urbanowska Z., Cudzoziemiec, Warszawa 1912.

Wodzicka T., Ze zwierzeń dziewczęcych. Pamiętnik Zofii z Matuszewiczów Kickiej 1796-1822, Kraków 1910.

Woykowska J., Z Kudowy, Poznań 1850.

Zieleniewski M., Rys balneologii powszechnej, Warszawa 1873.

Zieleniewski M., Rys balneotechniki na użytek wtaścicieli $i$ zarzadów zdrojowisk tudzież lekarzy zdrojowych, Warszawa 1890.

Zieliński A., Listy ze ślaskich wód, Wrocław-Warszawa-Kraków-Gdańsk 1983.

Zieliński A., Polskie podróże po Ślasku w XVIII i XIX wieku, Wrocław-Warszawa-Kraków-Gdańsk 1974.

\section{Reminiscences of Poles traveling in the Sudetes based on $19^{\text {th }}$-century accounts}

\section{Summary}

The article presents the stages of gradual exploration of the Sudetes over the centuries. Before tourism developed in the Sudetes, many facilities were subject to religious worship, first pagan, then Christian, as well as economic interest. For example mining, metallurgy, glass-making and herbal activities were carried out in them. Tourist interest in the mountains began gaining momentum after the $17^{\text {th }}$ century, with its climax in the $19^{\text {th }}$ century. Rapid development of tourism at that time occurred as a result of the activities of tourist organizations located in the Sudetes. The task of these organizations was to create infrastructure adequate for tourism, such as hiking trails, shelters and observation towers. The Sudetes were most often visited by patients who stayed in the spas located at the base of the mountains. Many Polish descriptions of the Sudetes have been preserved in the $19^{\text {th }}$ century literature. Visitors combined their observations with various themes, such as natural, scenic, historical, patriotic, religious, socio-economic. There were valuable notes containing regional legends or information about prevailing habits and customs, as well as rules existing in spas. Emotions accompanying the tours were often emphasized in these descriptions, therefore the article attempts to show the impressions of the places visited. 
dr Aneta Marek - adiunkt w Zakładzie Geografii Regionalnej i Turystyki Instytutu Geografii i Rozwoju Regionalnego Uniwersytetu Wrocławskiego. Specjalizuje się w historii turystyki górskiej i wysokogórskiej, turystyki kulturowej i geoturystyki

(aneta.marek@uwr.edu.pl)

Aneta Marek, PhD - assistant professor at the Department of Regional Geography and Tourism in the Institute of Geography and Regional Development at the University of Wrocław. She specializes in the history of mountain and high-mountain tourism, cultural tourism and geotourism

(aneta.marek@uwr.edu.pl) 